\title{
Development of Layer I Neurons in the Primate Cerebral Cortex
}

\author{
Nada Zecevic ${ }^{1}$ and Pasko Rakic ${ }^{2}$ \\ ${ }^{1}$ Department of Neuroscience, University of Connecticut School of Medicine, Farmington, Connecticut 06030-3401, and \\ 2Section of Neurobiology, Yale University School of Medicine, New Haven, Connecticut 06510-8001
}

Layer I, which plays an important role in the development of the cerebral cortex, expands in size and diversity in primates. We found that, unlike in rodents, in the macaque monkey, neurons of this layer are generated during the entire 2 month period of corticogenesis, within the middle of the 165-d-long gestation. The large, classical Cajal-Retzius cells, immunoreactive to reelin and calretinin but not to GABA, are generated first [embryonic day 38 (E38)-E50], with the peak of $\left[{ }^{3} \mathrm{H}\right]$ thymidine $\left(\left[{ }^{3} \mathrm{H}\right] \mathrm{TdR}\right)$ labeling at E43. Ultrastructural analysis revealed that processes of these cells form a stereotyped, rectangular network oriented parallel to the pial surface. Genesis of smaller, GABAergic neurons begins slightly later (E43), reaches a peak of $\left[{ }^{3} \mathrm{H}\right] \mathrm{TdR}$ labeling between E54 and E70, and continues until the completion of corticogenesis (E94). These late-generated layer I cells are imported from outside sources such as the olfactory primordium and ganglionic eminence and via a massive subpial granular layer that may also supply some GABAergic interneurons to the subjacent cortical plate. The ratio of large-to-small layer I neurons changes differentially, indicating that each class is produced and/or eliminated at a different rate and suggesting that their roles in primates are diverse.

Key words: neurogenesis; neuronal migration; neocortex; Cajal-Retzius cells; reelin; macaque monkey
Layer I, also called the plexiform layer because of the richness in fibers and the paucity of cells, was initially described in the human fetal cerebrum (Magini, 1888). The imposing, large neurons, with characteristic dendritic arbor, that bear the name of Cajal and Retzius (C-R cells) were illustrated in exquisite detail soon after the advent of the Golgi method (Martinotti, 1890; Ramon y Cajal, 1891; Retzius, 1893). Although these cells have continued to fascinate investigators, a recent discovery that they produce reelin, a glycoprotein essential for orderly neuronal cell migration and ingrowth of afferents into the cerebral cortex, has augmented this attention (D'Arcangelo et al., 1995, 1997; Ogawa et al., 1995; Del Rio et al., 1997; Nakajima et al., 1997; Curran and D'Arcangelo, 1998). It was also suggested that C-R cells may be involved in developmental disorders of the cerebral cortex in humans (Rakic and Caviness, 1995; Clark et al., 1997; Impagnatiello et al., 1998; Hong et al., 2000).

The size and pattern of dendritic and axonal arborization of layer I neurons are more elaborate in primates. In addition, the subpial granular layer (SGL), present transiently beneath the pia in the human fetal telencephalon, is absent or minimal in other mammals (Brun, 1965; Kostovic et al., 1985; Gadisseux et al., 1992; Meyer and Gonzalez-Hernandez, 1993; Zecevic and Milosevic, 1997; Meyer et al., 1998). Finally, the biochemical makeup of $\mathrm{C}-\mathrm{R}$ cells in humans is different from that in rodents (Meyer and Goffinet, 1998; Meyer et al., 1998; Zecevic et al., 1999). A number

\footnotetext{
Received Dec. 19, 2000; revised March 19, 2001; accepted April 4, 2001.

This work was supported by grants from the National Institutes of Health (P.R. and N.Z.). We thank John Rubenstein, Stewart Anderson, Masaharu Ogawa, and Andre Goffinet for the probes and antibodies as well as Maria Donoghue and Nenad Sestan for their assistance in preparation of this material. Timed pregnant monkeys were obtained from the breeding colonies of nonhuman primates at Yale University School of Medicine and the New England Regional Primate Center (Southborough, MA).

Correspondence should be addressed to Dr. Pasko Rakic, Section of Neurobiology, Yale University School of Medicine, New Haven, CT 06510. E-mail: pasko.rakic@yale.edu.

Copyright (C) 2001 Society for Neuroscience $\quad 0270-6474 / 01 / 215607-13 \$ 15.00 / 0$
}

of studies have raised the issue of the uniformity of $\mathrm{C}-\mathrm{R}$ cell populations with respect to their antigen content that are expressed either permanently or transiently and in various combinations by these neurons (Huntley and Jones, 1990; Verney and Derer, 1995; Lavdas et al., 1999; Meyer et al., 1999, 2000; Zecevic et al., 1999). Do all C-R cells in primates belong to a single class, or instead should they be classified into different subtypes on the basis of their antigen content, survival rate, or function? Would each subtype of layer I neurons have a different time of birth and/or different origin and function? How large are speciesspecific differences, and how are they related to the development and evolution of the neocortex?

The present study was undertaken to analyze the development and organization of cortical layer I in macaque monkey using $\left[{ }^{3} \mathrm{H}\right]$ thymidine autoradiography, electron microscopy, immunohistochemistry, and in situ hybridization methods that cannot be used effectively in the postmortem human brain.

\section{MATERIALS AND METHODS}

Autoradiography. The protocols for obtaining timed pregnancies and administration of $\left[{ }^{3} \mathrm{H}\right]$ thymidine $\left(\left[{ }^{3} \mathrm{H}\right] \mathrm{TdR}\right)$ have been described previously in full detail (Rakic, 1973). In short, 17 pregnant monkeys (Macaca mulatta) ranging in gestational age from embryonic day 36 (E36) to E110 (see Table 1 ) were injected intravenously with $\left[{ }^{3} \mathrm{H}\right]$ methyl thymidine $(10$ $\mathrm{mCi} / \mathrm{kg}$; $40-60 \mathrm{Ci} / \mathrm{mmol}$; New England Nuclear). The fetuses were born and survived for up to 4 months after birth. An additional eight pregnant monkeys were injected in selected gestational ages (E45, E58, E69, E86, E90, E110, E120, and E140), and the fetuses were killed $1 \mathrm{hr}$ after isotope injection to determine the location of dividing cells that are in the $\mathrm{S}$ phases of the mitotic cycle.

Postnatal animals were initially anesthetized with ketamine $(0.1 \mathrm{ml} /$ $\mathrm{kg}$ ) supplemented immediately before perfusion with sodium pentobarbital $(40 \mathrm{mg} / \mathrm{kg})$. All animals were perfused intravenously with buffered mixed aldehydes (Rakic, 1972). After perfusion, the cerebral hemispheres were dissected and embedded in polyester wax. Sections cut at 8 $\mu \mathrm{m}$ thickness were mounted on microscope slides and dipped in Kodak NTB emulsion. After being stored in darkness at $4 C^{\circ}$ for $4-10$ weeks, the slides were developed and stained with toluidine blue.

The presence of heavily radiolabeled cells in layer I was examined in 


\begin{tabular}{|c|c|c|c|c|c|c|}
\hline Age/region & Motor & Sensory & Visual & Prefrontal & Insulular & Limbic \\
\hline E36-P54 & 0 & 0 & 0 & 0 & 0 & 0 \\
\hline E38-P60 & 0 & 0 & 0 & 0 & 0.0075 & 0 \\
\hline E40-P62 & 0.12 & 0.07 & 0.05 & 0 & 0.07 & 0.03 \\
\hline E43-P70 & 0.56 & 0.76 & 0.8 & 0.3 & 0.99 & 0.41 \\
\hline E45-P58 & 0.45 & 0.64 & 0.53 & 0.4 & 0.9 & 0.15 \\
\hline E48-P110 & 1.16 & 0.9 & 0.16 & 0.4 & NA & 0.23 \\
\hline E50-P61 & 0.12 & 0.27 & 0 & 0.36 & 0.34 & 0.87 \\
\hline E54-P66 & 0.73 & 0.32 & 0.6 & 1.24 & 0.5 & 0.65 \\
\hline E70-P98 & 1.2 & 0.94 & 0.84 & 0.4 & 0.97 & 0.6 \\
\hline E85-P94 & 0.6 & 0.23 & 0.23 & 0.25 & 0.23 & 0.05 \\
\hline E90-P63 & 0.21 & 0.36 & 0.36 & 0.14 & 0.64 & 0.07 \\
\hline E94-P90 & NA & 0.12 & NA & 0 & 0.05 & 0 \\
\hline E102-P65 & 0 & 0.06 & 0 & 0 & 0 & 0 \\
\hline E110-P62 & 0 & 0 & 0 & 0 & 0 & 0 \\
\hline
\end{tabular}

NA, Not available.

six cortical areas (motor, sensory, visual, limbic, prefrontal, and insular) in a series of 10 sections, covering a $50,000 \mu \mathrm{m}$ length of layer I per cortical region per animal. Only the heavily labeled neurons (that is, those with no $<50 \%$ of grains encountered in the most intensively labeled nucleus in a given section) were considered to be divided at the time of $\left[{ }^{3} \mathrm{H}\right] \mathrm{TdR}$ injection (Rakic, 1973). A total length of $300,000 \mu \mathrm{m}$ of layer I per animal has been examined to record the number of heavily labeled cells that were classified as either $\mathrm{C}-\mathrm{R}$ or small neurons on the basis of their size and morphology. In addition, the total number of neurons has been counted in all cortical areas examined in this study on toluidine-stained sections processed previously for autoradiography. The total number of layer I neurons was calculated as the mean value in each cortical area from five 2- to 3-month-old animals, and the number of labeled $\mathrm{C}-\mathrm{R}$ and small neurons was expressed as a percentage of the total cell counts in layer I at the particular cortical region.

Light and electron microscopy. The tissue blocks from the somatosensory, visual, motor, and prefrontal areas were dissected from 27 macaque monkeys ranging in age from E41 to 20 years. Because a distinction between the somatosensory and motor areas could not be made before E80, in younger stages we examined blocks taken from the lateral cerebral wall. Cell density in layer I and the distribution of C-R cells in different cortical areas at each time point were determined by the light microscope using $1 \mu \mathrm{m}$ toluidine blue-stained sections or $8 \mu \mathrm{m}$ cresyl violet-stained paraffin sections.

The mean number of neurons in layer I cells per unit of cortical volume was calculated in each area from the plots made with the aid of a drawing tube attached to a Zeiss research microscope, at a magnification of $350 \times$ and $1000 \times$. The number of C-R cells was determined at E89, E144, birth (E165), and 7 months of age [postnatal day 222 (P222)]. Three plots per cortical area were made for each case. Counts of $\mathrm{C}-\mathrm{R}$ cells per surface area of $1.5-\mu \mathrm{m}$-thick sections were corrected using the Abercombie formula (Abercombie, 1946). The mean circular diameter of the C-R cells was calculated with the imaging system for each age group and area separately, at a magnification of $2040 \times$. In adult animals, C-R cells became sparse, and the distinction between them and other neurons found in layer I was not always possible at the light microscopic level.

Electron microscopic analysis was performed to determine ultrastructural characteristics and changes in the differentiation of cells and their processes in layer I. All monkeys, embryonic as well as adults, were perfused through the circulatory system with mixed gluteraldehyde and/or paraformaldehyde fixative and processed for electron microscopic analysis (Rakic, 1972). Some of these cases were also used as parts of other studies (Rakic, 1972, 1973; Zecevic and Rakic, 1991).

Immunohistochemistry. The immunohistochemical study was based on cortical tissue obtained from five macaque monkey embryos at E40, E65, E80, E81, and E90 and two adult monkeys 4 and 5 years old. The embryos were delivered by Cesarean section; cerebral tissue was dissected from the cerebral wall and immersed in isopentane cooled in liquid nitrogen to $-70^{\circ} \mathrm{C}$. Adult monkeys were perfused through the circulatory system with $4 \%$ paraformaldehyde. Brain tissue was dissected and stored in the same fixative for $24 \mathrm{hr}$ at $4^{\circ} \mathrm{C}$, before freezing the tissue blocks as described above. Fourteen micrometer sections were cut at $-20^{\circ} \mathrm{C}$. They were subsequently washed three times for 5 min each in PBS. A blocking agent, made of $1 \%$ bovine serum albumin (BSA) and $5 \%$ normal goat serum (NGS) in PBS, was applied for $30 \mathrm{~min}$. Different primary antibodies were used: anti-calbindin D28k (Sigma, St. Louis, MO), antiparvalbumin (Sigma), anti-calretinin (SWant), SMI-31 (the phosphorylated form of neurofilament protein; Sternberger Monoclonals, Inc.),

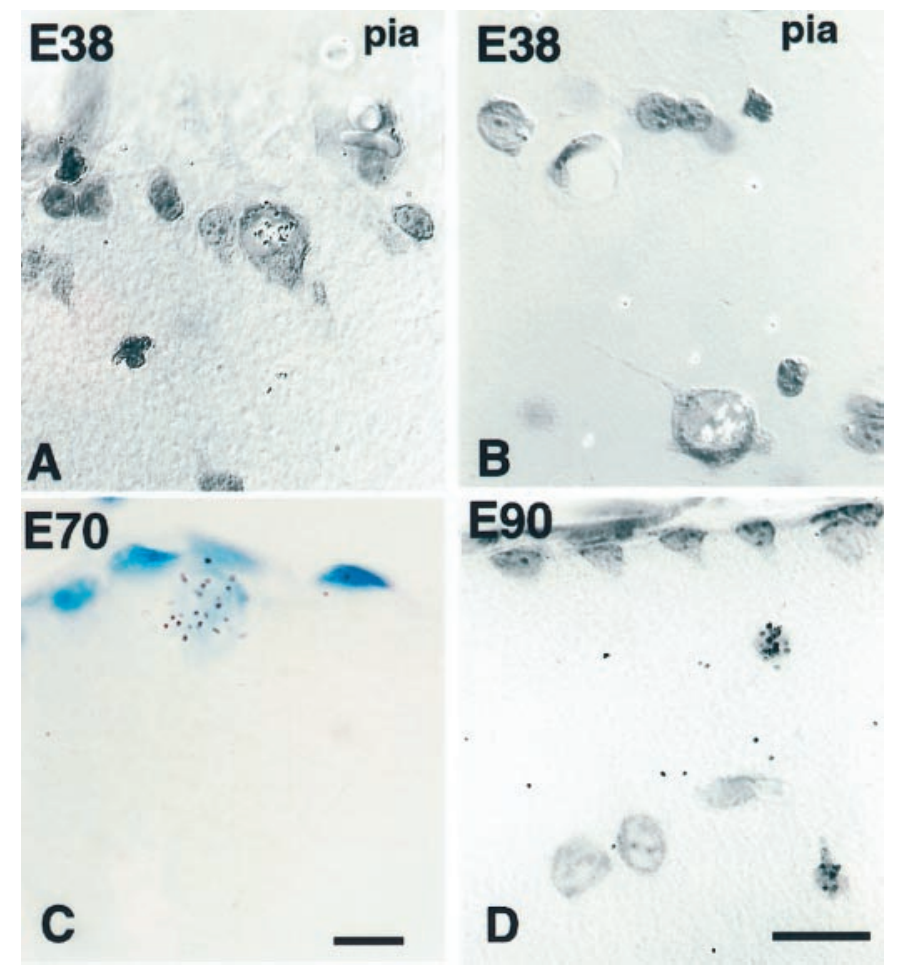

Figure 1. Autoradiogram of 2-month-old monkeys. A, B, Labeled C-R cells in layer I of monkey motor cortex injected with $\left[{ }^{3} \mathrm{H}\right]$ thymidine at E38. Note that these early born $\mathrm{C}-\mathrm{R}$ cells remain in layer I after birth, either under the pia $(A)$ or deeper in layer $\mathrm{I}(B)$. $C$, Animal injected at E70. $D$, Small neurons in animal injected at E90. Scale bar, $10 \mu \mathrm{m}$. Nomarski, $63 \times$. 
PREFRONTAL CORTEX

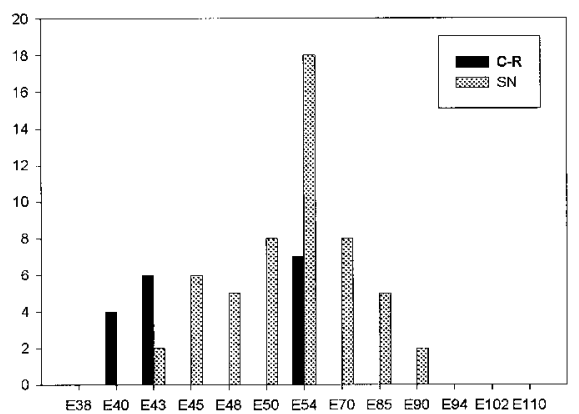

INSULAR CORTEX
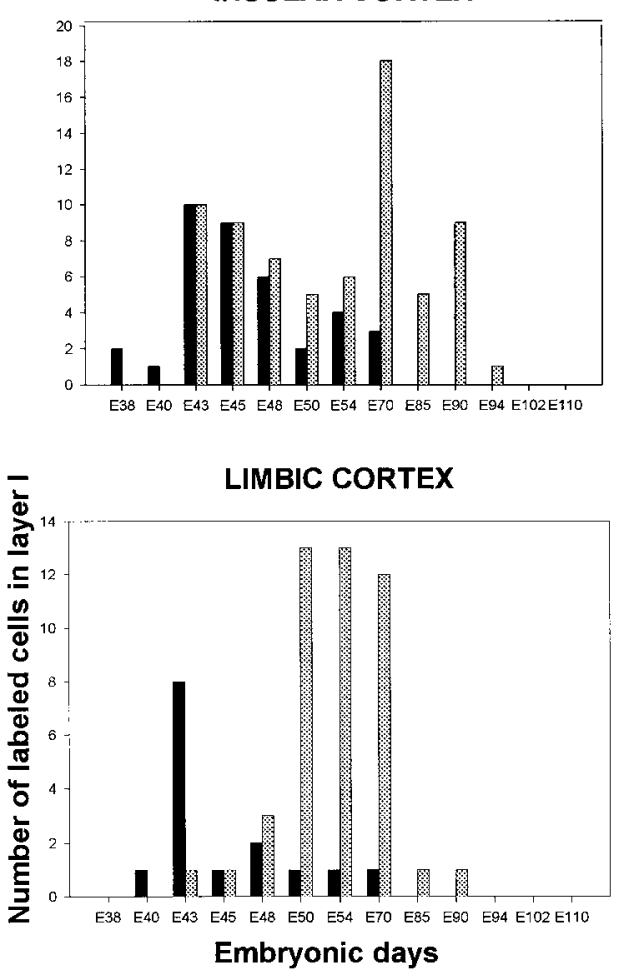

MOTOR CORTEX

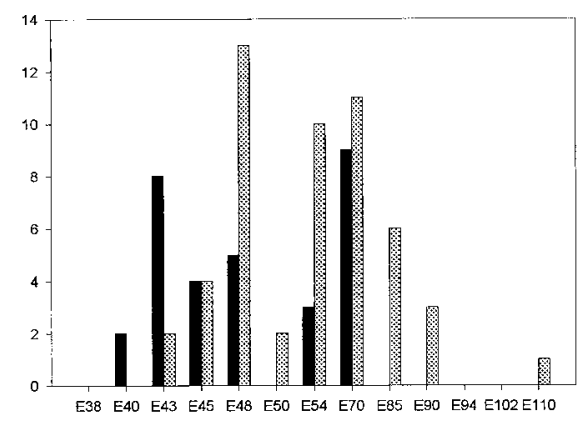

SENSORY CORTEX

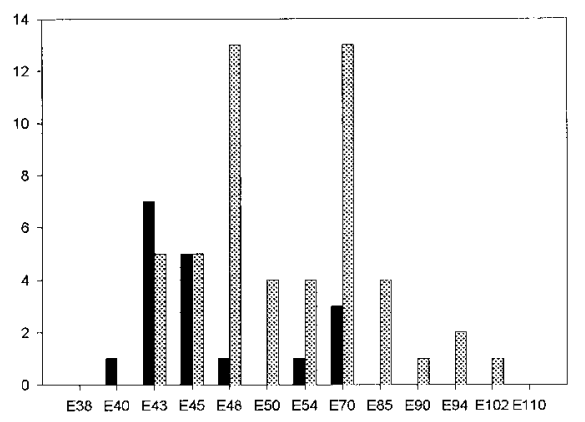

VISUAL CORTEX

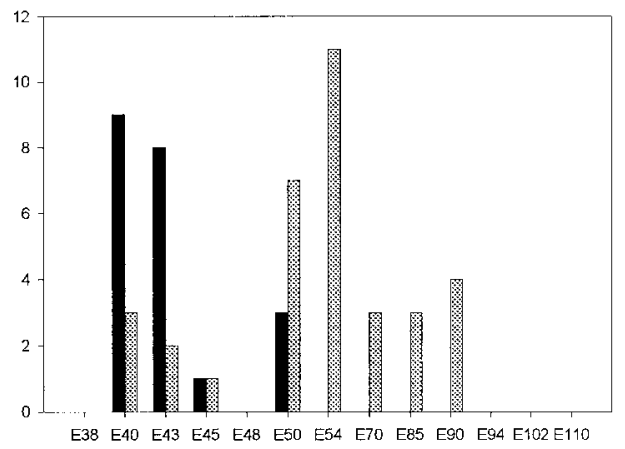

Figure 2. Histograms represent the number of $\left[{ }^{3} \mathrm{H}\right]$ thymidine-labeled neurons $(y$-axis) in a unit length of layer I $(50,000 \mu \mathrm{m})$ in six cortical areas estimated at 2 postnatal months, after single-pulse labeling at various embryonic days ( $x$-axis). Note that all $\mathrm{C}-\mathrm{R}$ cells are born by E70, whereas non $\mathrm{C}-\mathrm{R}$ cells, small neurons and glia, continue proliferation until E102-E110. SN, Small neurons.

anti-proliferating cell nuclear antigen (PCNA; Dako, Carpinteria, CA), and anti-reelin (CR-50, gift of Dr. Ogawa, and antibody 142, gift of Dr. Goffinet). Primary antibodies remained overnight at $4^{\circ} \mathrm{C}$. The next day, sections were washed three times in PBS. Biotinylated secondary antibodies were used in a 1:100 dilution for $1 \mathrm{hr}$. Further reaction was done with an $\mathrm{ABC}$ Vector kit according to the manufacturer's instructions (Vector Laboratories, Burlingame, CA). In case of double labeling, we used a cocktail of primary antibodies followed by a cocktail of flurescineor rhodamine-conjugated secondary antibodies in a 1:200 dilution. Controls were treated in the same way with omission of the primary antibody, which resulted in the absence of the immunostaining. Cross-reactivity of secondary antibodies was also tested.

In situ hybridization. In situ hybridization was performed according to the method of Donoghue and Rakic (1999a). Briefly, slides containing freshly cut embryonic monkey brains were incubated in the following series of solutions at room temperature (RT): (1) $4 \%$ paraformaldehyde, $\mathrm{pH}$ 7, for $10 \mathrm{~min}$, (2) PBS for 10 min, (3) $0.75 \%$ glycine in PBS twice for 3 min each, (4) PBS for $5 \mathrm{~min}$, (5) $0.1 \mathrm{M}$ triethanolamine (TEA) buffer for $5 \mathrm{~min}$, (6) $0.1 \mathrm{M} \mathrm{TEA}$ containing $500 \mu \mathrm{l}$ of acetic anhydride for $10 \mathrm{~min}$, (7) $0.1 \mathrm{M}$ TEA for $5 \mathrm{~min}$, (8) $50,70,95$, and $100 \%$ ethanol for $2 \mathrm{~min}$ each, (9) chloroform for $5 \mathrm{~min}$, and (10) 100\% ethanol twice for 2 min each. Dlx-1 probe was diluted in hybridization solution and denatured at $100^{\circ} \mathrm{C}$ for $2 \mathrm{~min}$. Hybridization solution, containing probe $\left(3 \times 10^{6}\right.$ in a volume of $120 \mu \mathrm{l}$ ), was then spread over each section, and a coverslip was placed over this solution and sealed. Slides were then incubated in a humidified chamber at $65^{\circ} \mathrm{C}$ for at least $16 \mathrm{hr}$. After hybridization, slides were incubated in the following series of solutions: (1) $2 \times$ SSC for $15 \mathrm{~min}$ at RT, (2) $0.5 \times \mathrm{SSC}$ for $5 \mathrm{~min}$ at RT, (3) $0.1 \times \mathrm{SSC}$ for $20 \mathrm{~min}$ at $65^{\circ} \mathrm{C}$, (4) $1 \times$ RNase buffer for $5 \mathrm{~min}$ at $37^{\circ} \mathrm{C}$, (5) $20 \mu \mathrm{g} / \mathrm{ml} \mathrm{RNase} \mathrm{A} \mathrm{in} 1 \times$ RNase buffer for $30 \mathrm{~min}$ at $37^{\circ} \mathrm{C},(6) 1 \times$ RNase buffer for $30 \mathrm{~min}$ at $37^{\circ} \mathrm{C},(7) 2 \times$ $\mathrm{SSC}$ for $30 \mathrm{~min}$ at RT, (8) $0.1 \times \mathrm{SSC}$ twice for $10 \mathrm{~min}$ at $65^{\circ} \mathrm{C},(9) 0.1 \times$ SSC for $30 \mathrm{~min}$ at RT, and (10) 50, 70, 95, and $100 \%$ ethanol for $2 \mathrm{~min}$ each at RT. After exposure to film, the slides were dipped in NTB2 nuclear track emulsion (Kodak), exposed for $\sim 1$ month at $4^{\circ} \mathrm{C}$, developed, lightly counterstained with hematoxylin and bis-benzamide, coverslipped in glycerol, and photographed with either dark-field, fluorescent, or brightfield optics. Some sections were processed for immunoreaction after the completion of in situ hybridization (see Fig. 11).

\section{RESULTS}

\section{Time of neuron origin}

Heavily labeled neurons, representing cells that have entered their last cell division at the time of $\left[{ }^{3} \mathrm{H}\right] \mathrm{TdR}$ injections, were found in layer I of all postnatal animals injected between E38 and E94 (Figs. 1, 2; Table 1). If the injection was made after this embryonic period, no heavily labeled cells with neuronal characteristics could be detected in layer I of adult animals although the production of glial cells continues well into the postnatal ages as in the other cortical layers (Rakic, 1985). Thus, neurons compos- 
Figure 3. Autoradiograms of fetal monkeys injected with $\left[{ }^{3} \mathrm{H}\right]$ thymidine at various ages and killed $1 \mathrm{hr}$ after the injection. $A$, In the animal injected at E45, many cells are labeled in the proliferative ventricular zone $(V Z)$ and in the connective tissue above the pia (PIA), but only cells around the blood vessel $(b v)$ are labeled in the marginal zone and the thin cortical plate $(C P)$. $B$, In the animal injected at E69, two labeled cells (top arrowheads) are observed in the newly formed $S G L$ of the ventrolateral region of the cerebral vesicle; epithelial cells of the blood vessels are also labeled (arrowhead). $C, D$, Injections made at E120 $(C)$ and E140 $(D)$ labeled only cells above the pia and around blood vessels (arrowheads). Two unlabeled $\mathrm{C}-\mathrm{R}$ cells, born before the injections, are observed in layer I (arrows). A line is drawn in all photographs to delineate the pial membrane. Scale bar, $20 \mu \mathrm{m}$.
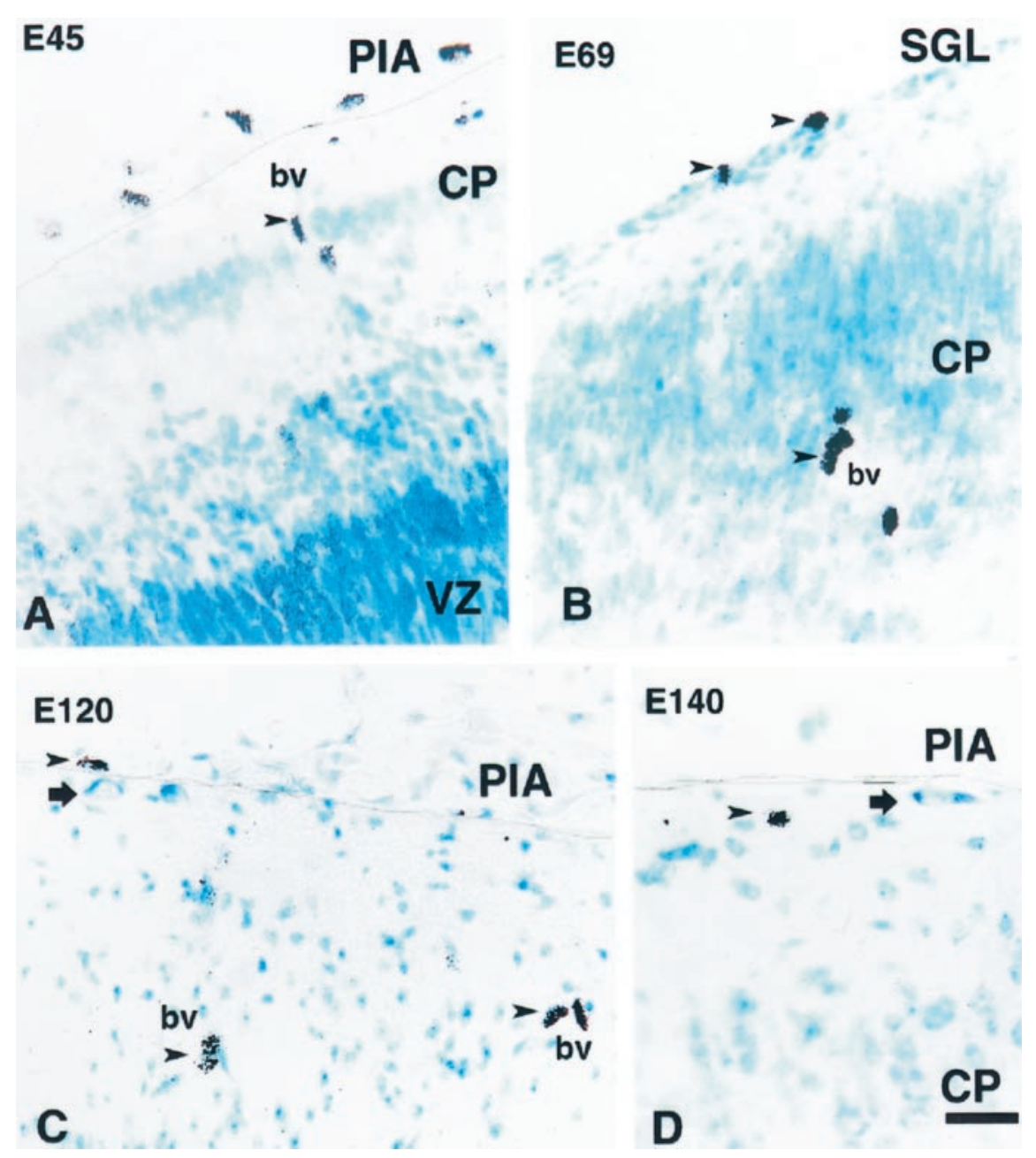

ing layer I in macaque monkey are born during the first two-thirds of the $165 \mathrm{~d}$ gestational period. The labeling index (percentage of $\left[{ }^{3} \mathrm{H}\right] \mathrm{TdR}$-labeled neurons in layer I) ranged from 0 to $1.24 \%$ (Table 1). Two peaks of neuronal proliferation were observed, between E43 and E45 and between E54 and E70 (Fig. 2).

Two types of neurons can be readily distinguished on toluidine-stained autoradiograms: large neurons representing C-R cells (cross-soma diameter of 13-20 $\mu \mathrm{m}$ ) and smaller neurons (cross-soma diameter of 9-11 $\mu \mathrm{m}$ ) (Fig. 1). Although cells cut tangentially were difficult to classify into either group, it was clear that the large $\mathrm{C}-\mathrm{R}$ cells were generated first. These cells are generated during a period of almost 1 month, between E38 and E70, with the peak of neurogenesis across all areas between E43 and E50 (Fig. 2). Large cells generated as early as E38 could be observed in postnatal animals either immediately below the pial membrane or deeper in layer I (Fig. 1). The labeled cells appeared first in the insular cortex (at E38) and at the latest in the prefrontal cortex (at E43). In some cortical regions, all C-R cells were born within a distinct short time span: for the prefrontal cortex between E43 and E50 and for the visual cortex between E40 and E50 (Fig. 2). In contrast, the genesis of small neurons of layer I starts later, at approximately E43, but persists until E94.

\section{Place of neuron origin}

To determine whether later-generated $\mathrm{C}-\mathrm{R}$ cells originate locally, we examined autoradiograms in the group of animals exposed to $\left[{ }^{3} \mathrm{H}\right] \mathrm{TdR}$ between E45 and E140 and killed $1 \mathrm{hr}$ after injection of the isotope (Fig. 3). During this developmental period of $\sim 3$ months (E45-E140), we only found an occasional radiolabeled cell in layer I. Some of these locally generated cells are likely to be glia, especially at the later gestational ages (Fig. 3).
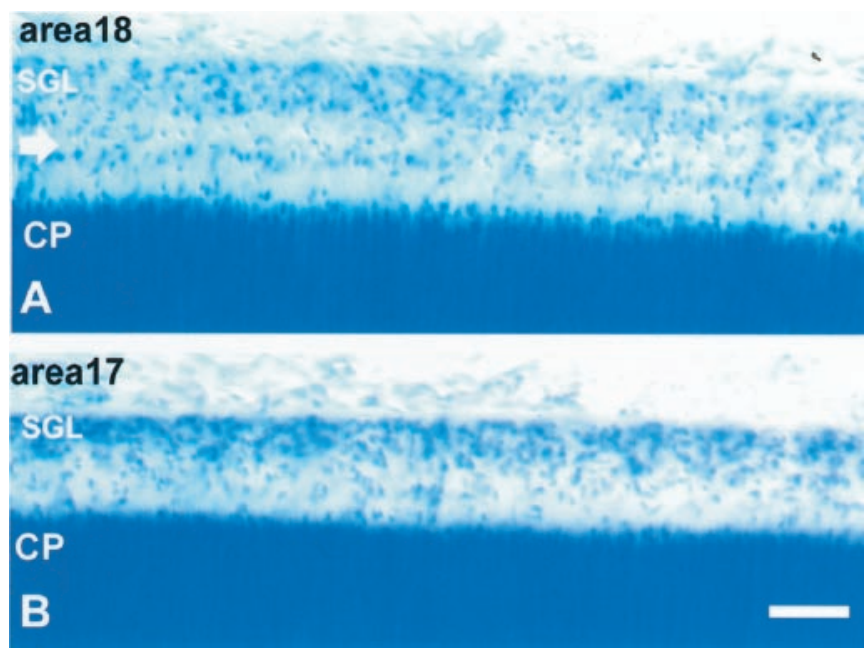

Figure 4. Nissl-stained sections of the occipital lobe in the E86 monkey cerebral cortex. $A$, Prospective area 18 shows a voluminous SGL as well as a distinct cell band (arrow) in the middle of layer I. $B$, In area 17, both the SGL and this cell band are smaller. Scale bar, $100 \mu \mathrm{m}$. 


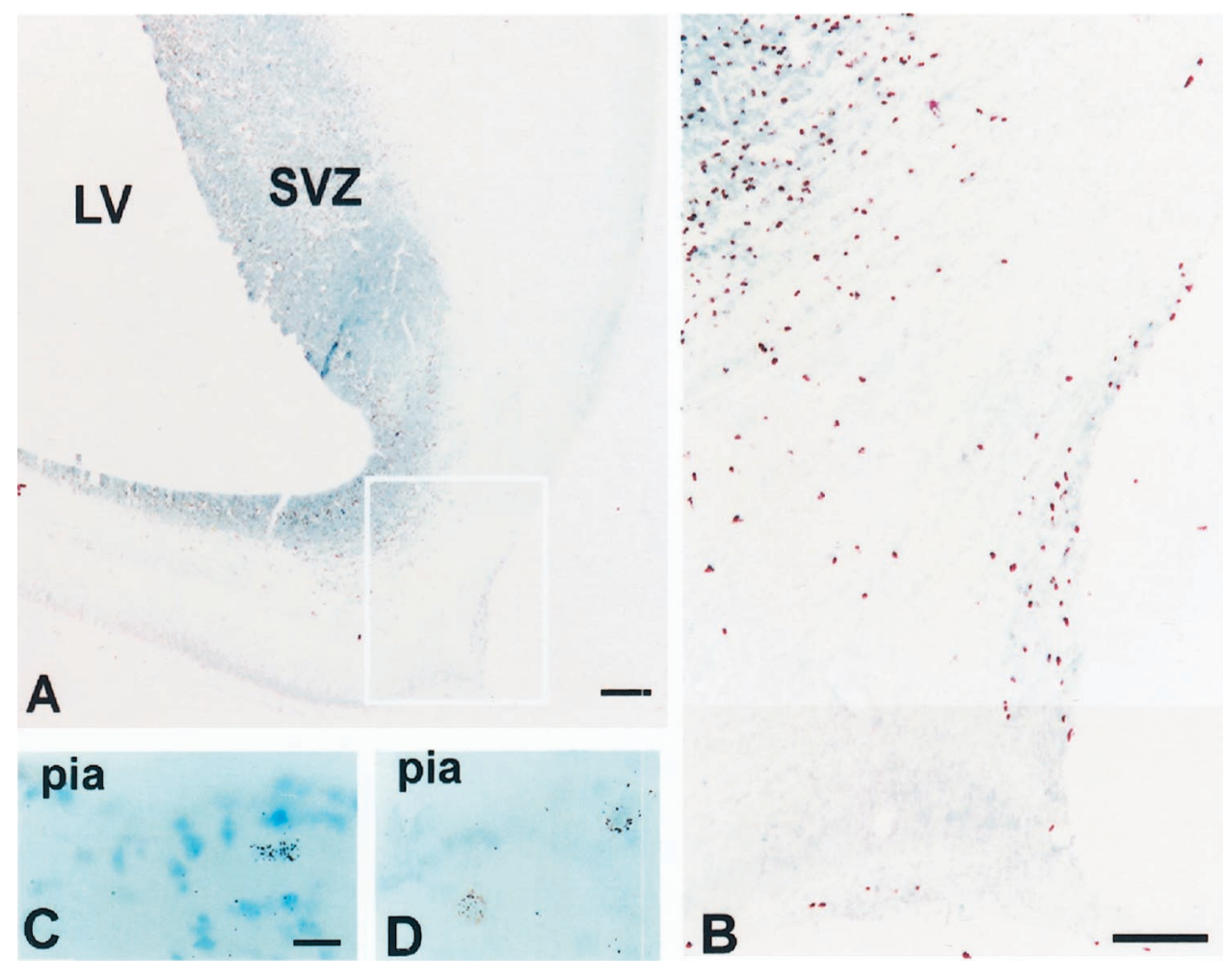

Figure 5. Autoradiograms of fetal monkeys injected with $\left[{ }^{3} \mathrm{H}\right]$ thymidine at different embryonic days. $A, B$, An animal injected at E69 and killed $1 \mathrm{hr}$ later. In $B$, a higher power of the area delineated in $A$ is shown. $C$, An animal injected at E70 and killed $3 \mathrm{~d}$ later at E73. $D$, An animal injected at E65 and killed $7 \mathrm{~d}$ later at E72. In all cases labeled cells are observed close to the pia, in the SGL. $L V$, Lateral ventricle; $S V Z$, subventricular zone. Scale bars: $A, 200$ $\mu \mathrm{m} ; B, 100 \mu \mathrm{m} ; C, D, 10 \mu \mathrm{m}$.

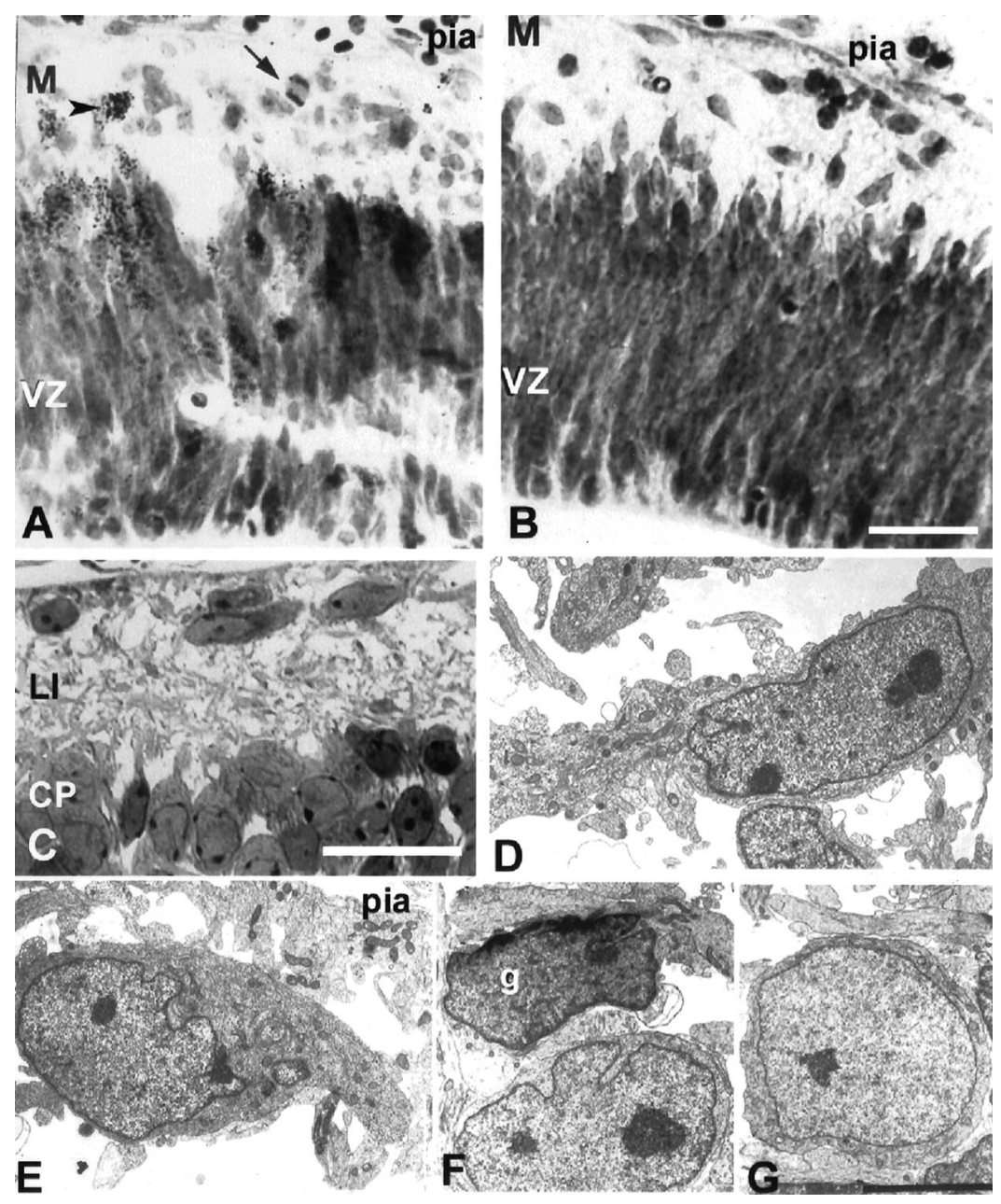

Figure 6. Cells below the pia at embryonic stages of cortical development. $A, B$, Nissl-stained section of E38 animal injected with $\left[{ }^{3} \mathrm{H}\right]$ thymidine $3 \mathrm{~d}$ earlier at E35 is shown. Note the labeled cell (arrowhead) and the mitotic figure (arrow). $C$, At E49, the $C P$ starts to form, and horizontally oriented C-R cells are visible below the pia. $D-G$, Electron micrograph of the immature C-R cells at E41 $(D)$ and E50 $(E)$ and small neurons in layer I at E41 $(F)$ and E50 $(G) . g$, Glia cell; $M$, marginal zone. Scale bars: $A-C, 25 \mu \mathrm{m} ; D-G, 5 \mu \mathrm{m}$. 
Figure 7. Tangential cut through layer I at midgestation (E89). A, Cell processes, probably dendrites, emerging from both poles of this bipolar $\mathrm{C}-\mathrm{R}$ cell. Close contact with the dendrite of another cell is indicated with the arrow. Much smaller cells represent either non-C-R cells or glial cells. $B$, Lipof uscinfilled inclusion in the cell body of another $\mathrm{C}-\mathrm{R}$ cell (arrow). $C$, Whirl of endoplasmic reticulum in the $\mathrm{C}-\mathrm{R}$ cell process. $D, \mathrm{C}-\mathrm{R}$ cells close to a $b v$, with an axon emerging from one end of the cell body (arrow) and a dendritic process emerging from the opposite end. Scale bars, $5 \mu \mathrm{m}$.
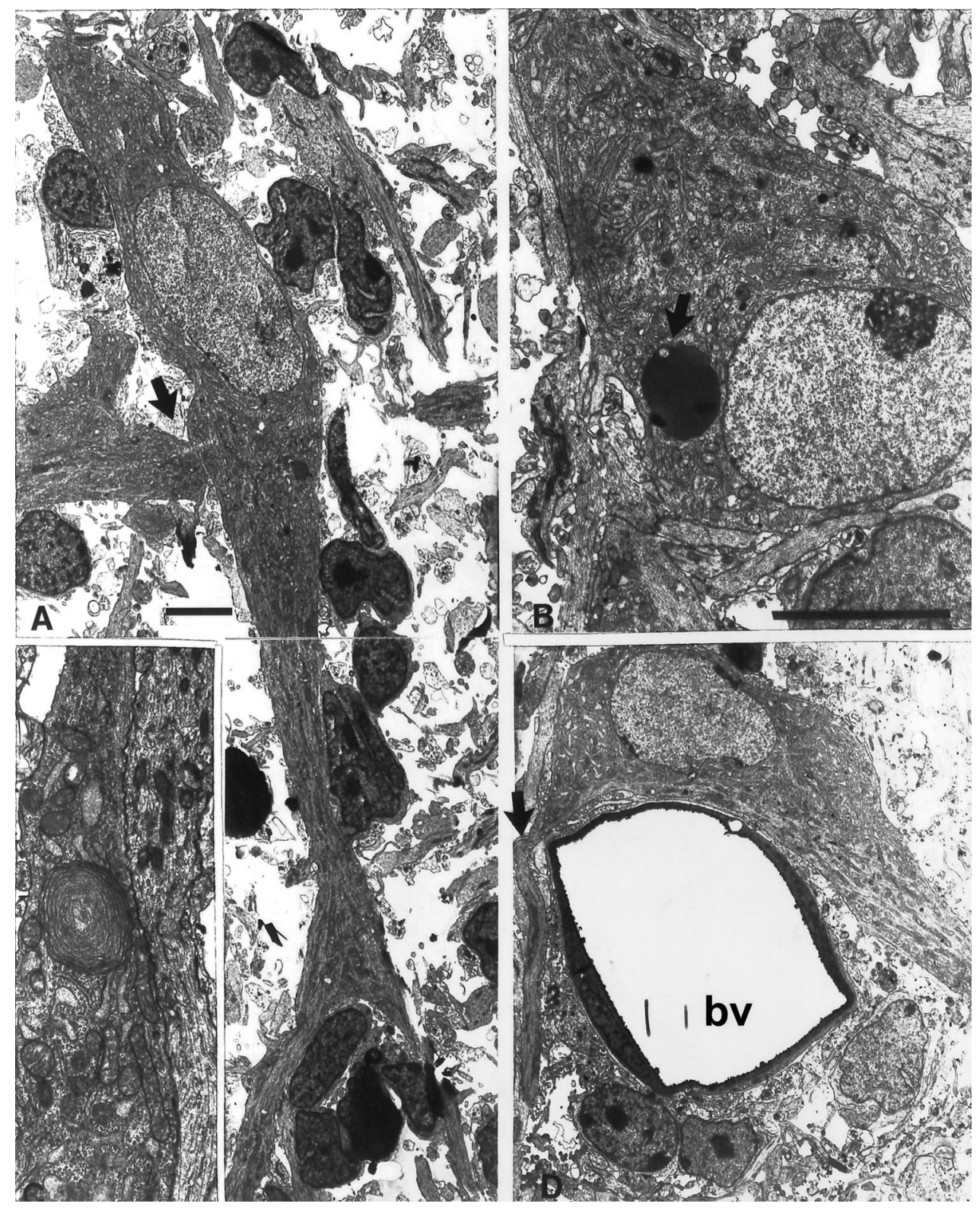

The reliability of our method was confirmed by the presence of numerous radiolabeled epithelial cells in layer I that were associated with growing capillaries. The largest number of $\left[{ }^{3} \mathrm{H}\right] \mathrm{TdR}-$ labeled cells in the SGL was observed in the E69 specimen in which three labeled cells were encountered in 20 autoradiograms that were examined (Fig. 3). Only five mitotic figures were observed in the SGL at either light or electron microscopic levels in the entire study. A low level of local neuron production is confirmed by immunoreaction to PCNA, a cyclin activated during mitosis. Positive reaction in the SGL was extremely rare, whereas many PCNA-immunoreactive cells were observed in the proliferative zones such as the ventricular and subventricular zones of the same specimens, confirming that immunolabeling works with this antibody (data not shown).

The paucity of radiolabeling in the SGL was surprising considering its large size in primates. This layer in the monkey becomes visible at approximately E58 as a one-cell-thick cellular band situated subjacent to the pial surface. However, it gradually grows in thickness until the fetal age of E75-E90, when it reaches a massive proportion (Fig. 4). It then begins to decline rapidly and becomes extinct at approximately E140. During its existence, the SGL shows areal differences in size and cell distribution. For example, at E86 in prospective area 17 of the occipital pole, it forms a single band of cells situated below the pial membrane (Fig. 4). In contrast, in area 18 of the same specimen, the SGL displays two distinct bands, one remaining below the pia and another displaced toward the middle of layer I (Fig. 4), suggesting initiation of a wave of inwardly migrating cells, which may have been already more advanced in the prospective area 17.

The fact that only five mitotic figures were observed in the SGL in the entire study indicates that the majority of cells in the SGL and layer I in general are imported from outside sources such as postmitotic neurons. We could not determine whether any of the locally divided cells would become neurons, but even if they do, their number produced within the SGL itself would be too small to account for all of the layer I neurons that are labeled in postnatal animals injected with $\left[{ }^{3} \mathrm{H}\right] \mathrm{TdR}$ at later stages of corticogenesis. Thus, the massive SGL in primates serves 


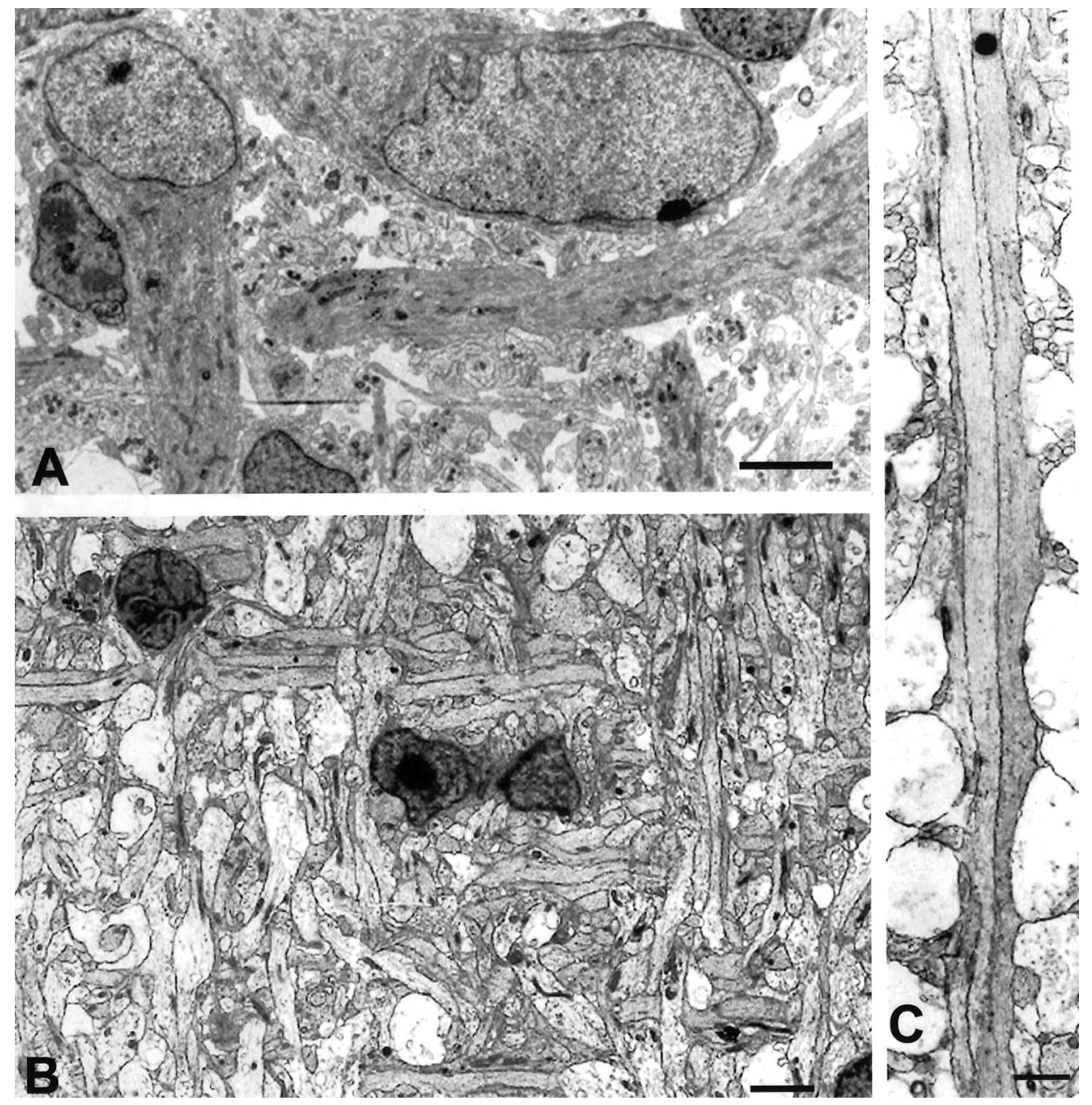

Figure 8. $A$, Tangential cut through layer I at E53 is shown. C-R cell processes are oriented parallel to the pia and at right angles to each other. $B$, At $\mathrm{E} 81$, cell processes in layer I, some of which belong to $\mathrm{C}-\mathrm{R}$ cells, exhibit an orderly mesh-like pattern. $C$, In the same E81 monkey, two C-R cell processes run parallel to each other and to the pial membrane for a considerable distance without forming specialized contacts. Scale bars: $A, B, 5 \mu \mathrm{m} ; C, 2 \mu \mathrm{m}$. mainly as a conduit of nondividing, postmitotic neurons, originating elsewhere and subsequently dispersed throughout layer I as well as to the subjacent cortical plate.

We used some of the cell class-specific markers to determine the origin of the late-generated reelin $(+)$ cells. The polyclonal antibody to the gene product $D l x-1$, which specifically stains cells derived from the ganglionic eminence (GE) in early development (Anderson et al., 1997), did not label C-R cells in the monkey neocortex between E65 and E81. However, this is likely to be an artifact because in situ hybridization performed with a probe for the Dlx-1 gene at E65 showed that some cells in layer I have a positive signal. Occasionally this expression of Dlx-1 mRNA would coincide with reelin $(+)$ cells (see Fig. 11), indicating that some of them were probably derived from the GE. However, in most sections, the grains were distributed more diff usely over the entire surface of layer I, indicating that this gene product may be preferentially expressed in the cytoplasm of dendritic and axonal arborizations. This finding indicates that in monkey, at least some cells in layer I may derive from the GE.

Examination of the autoradiographs in animals injected with $\left[{ }^{3} \mathrm{H}\right]$ thymidine between E65 and E75 and killed $1 \mathrm{hr}$ and 3 and $7 \mathrm{~d}$ later indicates that a major source of SGL in monkey may be the olfactory primordium (Fig. 5). For example, in the animal injected at E69 and killed 1 hr later, one can observe a distinct cohort of $\left[{ }^{3} \mathrm{H}\right] \mathrm{TdR}$-labeled cells in the marginal zone of the prospective olfactory cortex (Fig. $5 A, B$ ). However, in the animals injected at approximately the same embryonic stage and killed 3 or $7 \mathrm{~d}$ later, radiolabeled cells spread to the marginal zone of the neocortex (Fig. 5C,D) consistent with the hypothesis of their origin in the olfactory primordium and a migration within the prospective layer I without substantial proliferation.

\section{Cytology of layer I}

In the youngest specimen examined in the present study (E38), horizontally oriented cells were found in the formative marginal zone of the cerebral vesicle (Fig. 6). The immature appearance of these cells in Nissl-stained sections did not allow secure prediction of their respective fates. The same was true even in a slightly older embryo when horizontal cells become more numerous and the cortical plate begins to form ventrolaterally in the developing cerebral vesicles (E38-E41). However, after E41, we began to recognize three types of cells in the marginal zone: large cells with a light nucleus, smaller cells with a light nucleus, and cells with a dark, lobulated nucleus (Fig. 6). Large cells had prominent cytoplasm filled with free ribosomes, rows of endoplasmic reticulum, and a large nucleus (diameter of 10-13 $\mu \mathrm{m}$ ), elliptic or irregular in shape, with homogeneously distributed chromatin (Fig. 6). In instances in which the nucleus assumes an elliptic shape because of the plane of section, the longer axis was usually oriented parallel to the pia. These cells are often deployed in 


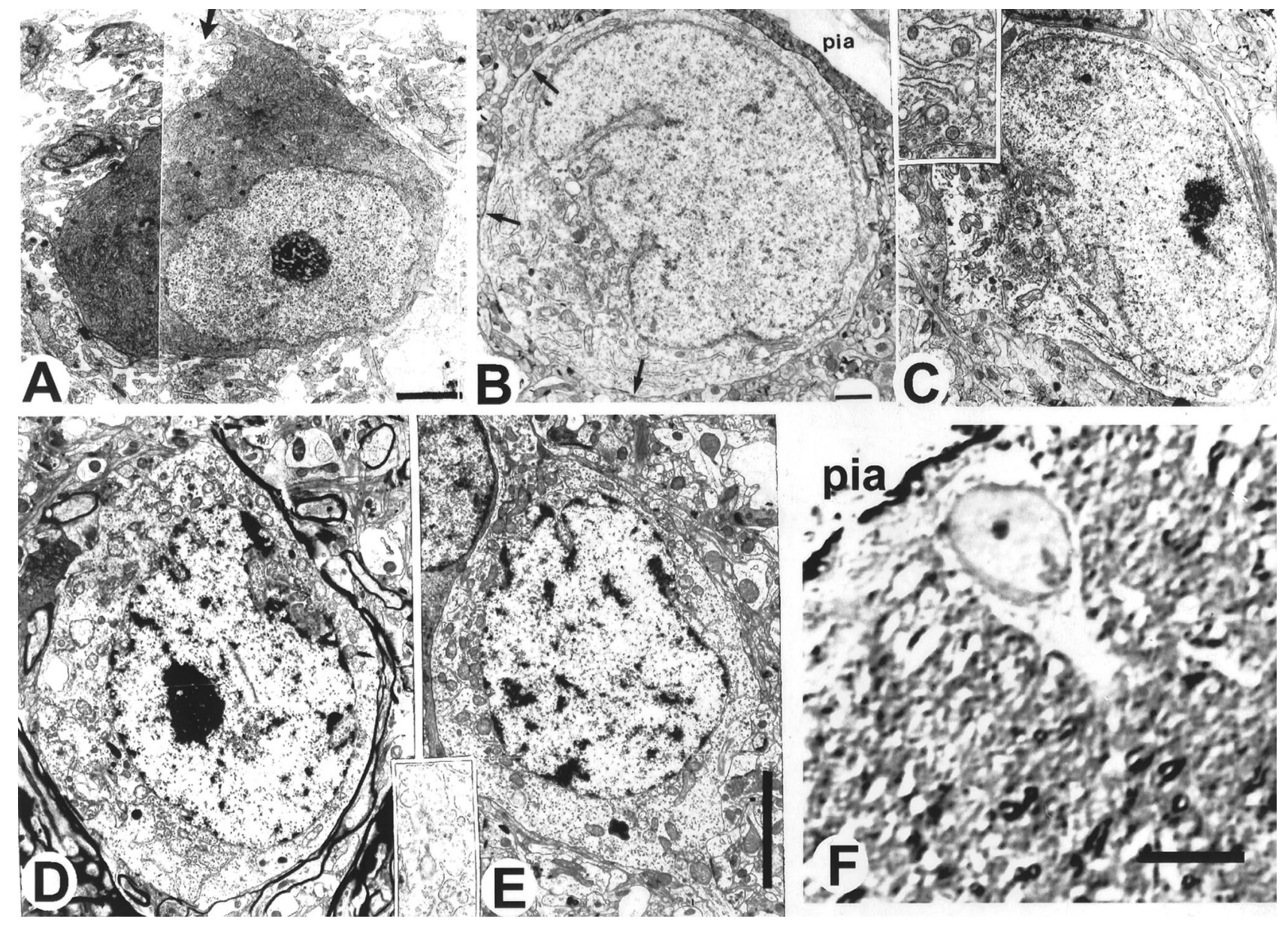

Figure 9. Electron micrographs of prenatal and postnatal layer I cells with typical morphology of the C-R cells. $A$, In the visual cortex in the E112 monkey, a large cell with eccentrically positioned nucleus, abundant cytoplasm with parallel rows of rough endoplasmic reticulum, and several thin processes emerging from the cell body (arrow). B, At 7 months of age (P222). Arrows point to axosomatic synapses. C, In a 4-year-old monkey, cells with $\mathrm{C}-\mathrm{R}$ morphology. Inset, The endoplasmic reticulum at higher magnification. Cisterns of endoplasmic reticulum at this age are scattered around the soma. $D, E$, Examples of two C-R-like cells at 10 years of age. A tangential cut through layer I is shown. Inset, At higher magnification, the breaking of parallel rows of rough endoplasmic reticulum. $F$, A large subpial C-R cell visualized on a $1 \mu \mathrm{m}$ Nissl-stained section of the motor cortex in a 20 -year-old monkey. Scale bars: $A, 2.5 \mu \mathrm{m} ; B, 1 \mu \mathrm{m} ; C-E, 5 \mu \mathrm{m} ; F, 30 \mu \mathrm{m}$.

groups of two or three in close contact, but without indication of synaptic junctions (Figs. 7, 8). A growth cone-like structure filled with "empty" vesicles could be seen to emanate from the cell body. Usually a prominent process emerges from the cell body and runs parallel to the pia (Figs. 7, 8). On the basis of these morphological and ultrastructural characteristics, we classified these neurons as $\mathrm{C}-\mathrm{R}$ cells. The second population of cells with a soma diameter of $6-11 \mu \mathrm{m}$ and a thin rim of cytoplasm was classified as small neurons (Figs. $6 F, G, 7$ ). The round or oval nucleus, with an evenly distributed chromatin, helps to distinguish them from glial cells, which are characterized by a lobulated, dark nucleus (Fig. 6F). The initial, homogeneously distributed nuclear chromatin that can be observed up to E70 starts to form clumps that made classification of these cells as glial more reliable (Fig. 7).

In the second half of gestation, $\mathrm{C}-\mathrm{R}$ neurons acquire light and electron microscopic characteristics and axonal and dendritic arborization that become the landmarks for these cells. The cell body became larger (up to a diameter of $26.5 \mu \mathrm{m}$ ) with a nucleus $(16.5 \mu \mathrm{m})$ situated usually in an eccentric position with indentations on one side and one or two nucleoli. The cytoplasm became more abundant with prominent rows of cisterns of the granular endoplasmic reticulum and multivesicular bodies organized as submembranous cisterns. Often large, dense granules varying in size from 0.06 to $0.2 \mu \mathrm{m}$ were observed, but typical $\mathrm{C}-\mathrm{R}$ cells without dense core vesicles could also be encountered (Fig. 7). Large inclusions (diameter of $2.5 \mu \mathrm{m}$ ) filled with dark material were often observed in the cell body, indicating programmed cell death (Fig. 7B). As development progresses, the initially dense ribosomes become diluted, making $\mathrm{C}-\mathrm{R}$ neurons stain lighter in comparison with the other cells of layer I.

Usually one large $(4-7 \mu \mathrm{m})$ and two to three thin $(0.2-0.5 \mu \mathrm{m})$ processes emanate from the neuronal cell bodies situated within layer I early stages. These processes, originating from neighboring cells, tend to be oriented perpendicular to each other (Figs. 7, 8). Sections cut tangentially to the pial surface were optimal for exposing the distribution of $\mathrm{C}-\mathrm{R}$ cells and the orientation of their processes in the marginal zone. In such sections, particularly at later embryonic stages, many $\mathrm{C}-\mathrm{R}$ cell processes running parallel to the pia displayed a remarkably precise perpendicular latticetype network (Fig. 8B). Occasionally, neurites were directed downward, perpendicular to the pial surface, making this arrangement three-dimensional. Often external membranes of adjacent $\mathrm{C}-\mathrm{R}$ cells and their processes were touching each other for 


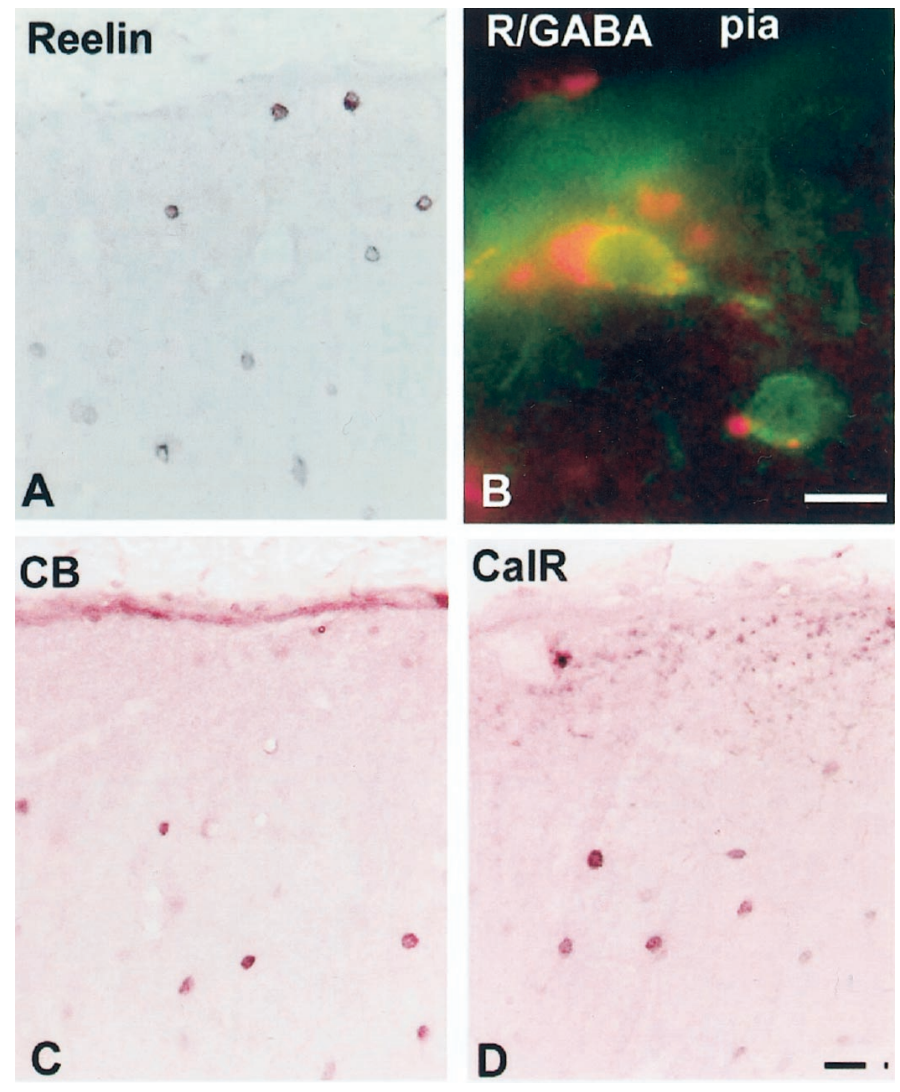

Figure 10. Immunohistochemistry of 5-year-old monkey visual cortex. $A$, Reelin-labeled cells both close to the pia and deeper in layer I. $B$, Double-labeling immunofluorescence with Reelin (secondary antibody conjugated with rhodamine; red) and GABA (secondary antibody conjugated with flurescine; green) revealing a $\mathrm{C}-\mathrm{R}$-like cell under the pia. $C, D$, Calbindin $(C B)$-labeled $(C)$ and calretinin $(C a l R)$-labeled $(D)$ neurons in layer I. Scale bars, $20 \mu \mathrm{m}$.

a considerable length without forming ultrastructurally recognizable membrane specializations (Fig. 8C). Axons, characterized by a uniform diameter and well expressed microtubules, ran parallel to the pial surface for a considerable distance, before running out of the plane of the section (Fig. 7D).

Cells with the light and electron microscopic characteristics attributed to the $\mathrm{C}-\mathrm{R}$ cells were also encountered in postnatal animals (Fig. 9). These cells are usually located either under the pial surface or deeper in layer I (Figs. 9, 10). In adult monkeys older than 4 years, C-R cells become sparse but nevertheless present in all specimens examined (Fig. 9C,D). They could be distinguished from the other cells of layer I by their size and more abundant rough endoplasmic reticulum (Fig. 9C). Their somas become almost completely wrapped by glial lamellas, except at the sites of synaptic junctions. At even older ages (10-20 years), C-R cells showed signs of deterioration of the fine cytoplasmic structures and an accumulation of lipof uscin granules, with chromatin distributed in clumps (Fig. 9D,E). However, large subpially located cells could be observed even in a 20 -year-old monkey (Fig. 9F).

\section{Biochemical characterization}

The combination of timing and distribution of expression of various antigens, known to be present in the layer I cells, displays distinct species-specific differences. Thus, reelin-immunoreactive cells in the macaque monkey could be observed in layer I at all fetal stages studied, from E40 to E90 (Fig. 11). The reaction product is usually localized in the cytoplasm, leaving the nucleus reaction free. Neuropil in the marginal zone, and later in layer I, showed a diffused reaction to reelin (Fig. 11). The reelinpositive $(+)$ cells were also always calretinin immunoreactive, whereas only a portion of reelin( + ) cells expressed calbindin (Fig. 11). The reelin $(+)$ cells, at fetal stages studied, did not show immunoreactivity to GABA, although other cortical cells such as those situated in the SGL or the intermediate zone and/or subventricular zone and occasional cortical plate cells were GABAergic (Fig. 11). Because most of the $\left[{ }^{3} \mathrm{H}\right] \mathrm{TdR}$ material was prepared before reelin antibodies were available, we could not combine it with immunocytochemistry. On the basis of the available information, it is reasonable to conclude that reelin $(+)$ large cells in the monkey fetus are equivalent to the $\mathrm{C}-\mathrm{R}$ cells of other species including humans.

In the adult monkey, cells labeled with reelin were regularly observed in layer I, close to the pia (Fig. 10A). The majority of these cells were smaller in size $(8-10 \mu \mathrm{m})$ than were prenatal $\mathrm{C}-\mathrm{R}$ cells, but some retain subpial localization and a larger size $(20 \mu \mathrm{m})$. Occasionally reelin was colocalized in the same neurons with GABA-immunoreactive cells (Fig. 10B), but single-labeled cells, either reelin or GABA positive, were also observed. A different population of small neurons in the middle of layer I was labeled with calretinin and calbindin (Fig. 10). We did not observe colocalization of either calretinin or calbindin in the same reelin-containing cells in the adult monkey.

\section{Quantitative data}

The density of C-R cells per unit volume of layer I was measured between E89 to P222 in the motor, sensory, visual, and prefrontal areas (Fig. 12). The peak in the number of $\mathrm{C}-\mathrm{R}$ cells per unit volume of layer $\mathrm{I}$ is reached by midgestation (E89) and then steadily decreases in all regions examined. In the next 2.5 months, from E89 to E165 (birth), the density of C-R cells declined to less than one-half of the peak value. The number continued to decline, and at the seventh postnatal month there were only 4-7 cells per $\mathrm{mm}^{3}$ of layer I, which is $70-80 \%$ less than that at midgestation $(\mathrm{E} 89 ; p<0.01)$. All cortical areas examined exhibited a similar decline of $\mathrm{C}-\mathrm{R}$ cell density. The density of $\mathrm{C}-\mathrm{R}$ cells in all ages was the highest in the motor and sensory cortices relative to that in the visual and prefrontal areas (Fig. 12).

Because the total volume of layer I in monkeys of different prenatal ages is unknown, we could not determine their absolute number at any given time. Although the density of $\mathrm{C}-\mathrm{R}$ cells was apparently diminished, it is not possible to determine to what extent it may be caused by apoptosis and by "dilution effect" related to the increase in the volume of layer I. For example, the ratio between the small neurons of layer I and $\mathrm{C}-\mathrm{R}$ cells at different age points in the sensory and motor cortices was always in favor of small neurons. However, in early embryonic life, this ratio was less $(2: 1)$ than in the first postnatal year (3:1) or in older animals (7:1). The total number of neurons in layer I declined from $30-40$ at 2 postnatal months to 25 cells per $1000 \mu \mathrm{m}$ of layer I at 1 year and even further to 15-20 in a 17-year-old animal (Table 2). This indicates that the population of $\mathrm{C}-\mathrm{R}$ cells is diminished by a combination of factors that include programmed cell death, antigen changes, and finally the process of dilution. 

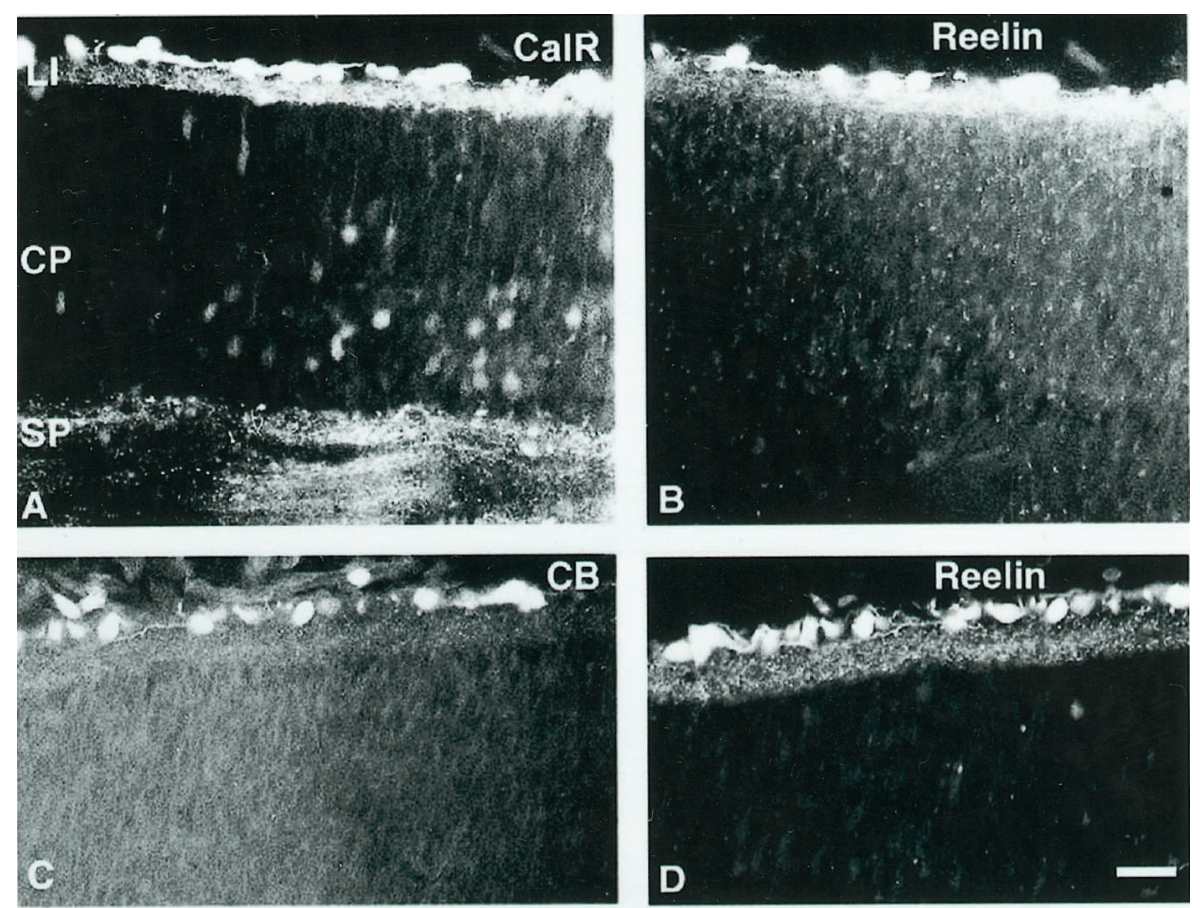

Figure 11. Double-labeling immunofluorescence of E65 $(A-D)$ and E85 $(E, F)$ monkey prefrontal cortex. $A, B$, Sections are labeled with CalR (secondary antibody conjugated with flurescine; $A$ ) and reelin (secondary antibody conjugated with rhodamine; $B$ ). Both markers are observed in the same $\mathrm{C}-\mathrm{R}$ cells immediately below the pia. $C, D$, Sections are labeled with $C B(C)$ and reelin $(D)$. Although many $\mathrm{C}-\mathrm{R}$ cells express both markers, not all reelin-labeled cells express calbindin. $E$, GABA (green) is expressed in small cells of the subpial granular layer, whereas reelin (red) is observed in C-R cells dispersed throughout this layer. $F$, Higher magnification displays reelin expression in the cytoplasm and not the nucleus of a C-R cell (arrow). G, Dark-field photograph of in situ hybridization with probe for Dlx-1 mRNA is shown. Arrows point to the in situ signal. H, Combined picture of Dlx-1 mRNA (grains) and immunofluorescence to reelin antibodies of E65 monkey neocortex are shown. Arrows point to colocalization of both signals. $L I$, Layer I; $S P$, subplate zone. Scale bars: $A-E, 60 \mu \mathrm{m} ; F-H, 20 \mu \mathrm{m}$.
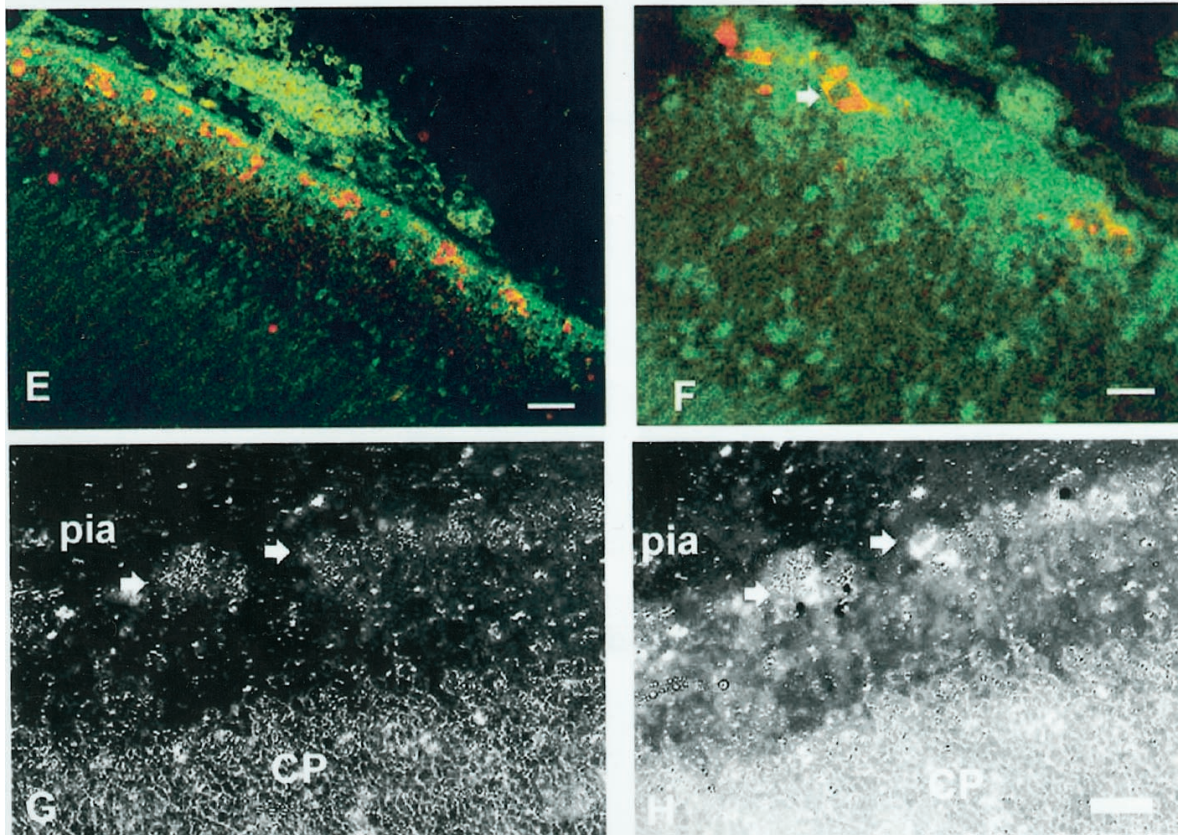

\section{DISCUSSION}

\section{Cytology and origin}

The present results, in agreement with the studies in humans (Meyer et al., 1999, 2000; Zecevic et al., 1999), demonstrate the presence of a larger number and a greater variety of layer I neurons in the primate cerebral cortex than in subprimate species. Furthermore, our study confirms that reelin alone cannot be taken as a cell class-specific marker for the $\mathrm{C}-\mathrm{R}$ cells without taking into consideration their size, morphology, and position. For example, large cells that morphologically resemble C-R cells are $\mathrm{GABA}(-)$ in fetal monkey, whereas a subpopulation of reelin $(+)$ cells in adult rodents are $\mathrm{GABA}(+)$ interneurons (Schiffmann et al., 1997; Alcantara et al., 1998; Pesold et al., 1998). In agreement with previous reports in human (Verney and
Derer, 1995; Meyer and Goffinet, 1998; Meyer et al., 1999; Spreafico et al., 1999; Zecevic et al., 1999) and monkey (Huntley and Jones, 1990), all reelin(+) C-R cells can be labeled with calretinin. In contrast, a smaller subpopulation of reelin $(+) \mathrm{C}-\mathrm{R}$ cells was also calbindin $(+)$.

Our $\left[{ }^{3} \mathrm{H}\right] \mathrm{TdR}$ autoradiographic analysis also revealed a considerable difference in the timing of genesis of layer I neurons compared with that of the nonprimate species. Although the early emergence of $\mathrm{C}-\mathrm{R}$ cells in monkey is in harmony with findings in the cat (Marin-Padilla, 1971), rat (Konig et al., 1977; Edmunds and Parnavelas, 1982) and mouse (Shoukimas and Hinds, 1978; Derer, 1985), the continuous addition of small neurons to layer I during the entire period of corticogenesis observed in the monkey stands in contrast to the short period of early genesis reported in 


\section{Number of C-R cells per $\mathrm{mm}^{3}$ of layer I}

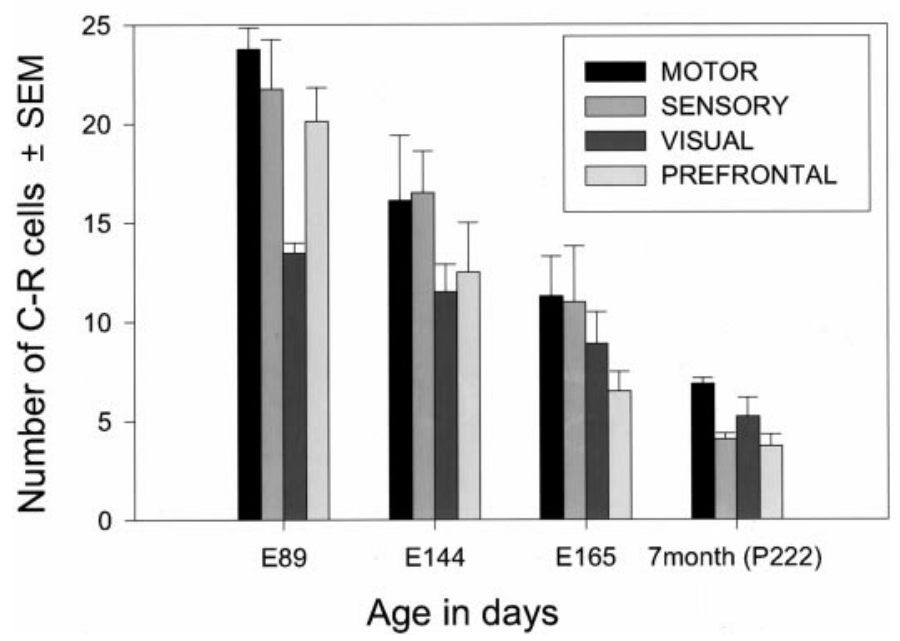

Figure 12. Histogram represents the number of $\mathrm{C}-\mathrm{R}$ cells per unit volume $\left(1 \mathrm{~mm}^{3}\right)$ of layer I in four cortical areas (motor, sensory, visual, and prefrontal) and at four time points.

all nonprimate species examined. Although it was suggested that the small number of layer I neurons in humans may originate from the SGL as well as from other sources, an experimental proof in primates has been lacking.

A traditional view was that $\mathrm{C}-\mathrm{R}$ cells originate from the periventricular zones and enter the embryonic $\mathrm{MZ}$ via radial migration before the formation of the cortical plate (for review, see Sidman and Rakic, 1973, 1982; see, however, Schaffer, 1918; Valverde et al., 1995; Meyer et al., 1998). Recently, it has also been suggested that the "pioneer," calretinin $(+)$ and calbi$\operatorname{ndin}(+)$, reelin(-) neurons come to the MZ from the ventricular zone and that the classical $\mathrm{C}-\mathrm{R}$ cells arrive at layer I later via the SGL (Meyer et al., 1998). However, our $\left[{ }^{3} \mathrm{H}\right] \mathrm{TdR}$ autoradiographic data revealed that in monkey the SGL appears only after the large C-R cells have been generated, and thus the SGL in primates contributes mostly to the later-generated layer I neurons.

Application of $\left[{ }^{3} \mathrm{H}\right] \mathrm{TdR}$ autoradiography and cell class-specific markers revealed that layer I cells in primates originate from a variety of sources including the olfactory primordium and GE. Somewhat reminiscent of the formation of the transient external granular layer, which supplies the granule cells to the developing cerebellar cortex by inward migration across the molecular layer (Ramon y Cajal, 1911; Rakic, 1971), the SGL may supply GABAergic neurons to the underlying cortical plate. The putative signals that prevent entrance of the glial-guided, radially migrating cells from the periventricular zones into the territory of layer I may not be recognized by the cells originating from other sources (Rakic, 1995; Anton et al., 1996). Indeed, it was shown in rodents that a subclass of cortical neurons originating in either the medial or lateral GE migrate tangentially and enter the cerebral cortex, including layer I (De Carlos et al., 1996; Anderson et al., 1997, 1999; Lavdas et al., 1999; Parnavelas, 2000; Wilson and Rubenstein, 2000). Transcription factors $D l x-1$ and $D l x-2$ are required for this migration, because in $D l x-1$ and $D l x-2$ mutant mice the number of $\operatorname{GABA}(+)$ neurons in layer I was reduced. Application of in situ hybridization in the present study revealed a Dlx-1 mRNA signal in some reelin-immunoreactive cells, suggesting that a subpopulation of layer I cells in macaque monkey might also originate from the lateral GE. Dual origin of layer I neurons has been suggested in mice in which a larger contingent of C-R cells express the Lhx6 gene, a specific marker for the medial GE cells (Lavdas et al., 1999). In agreement with studies in rodents, the Dlx-1(+) cells may come from the GE, whereas Dlx-1(-) GABAergic neurons observed in the primate layer I probably come from the olfactory primordium.

A major difference between layers I in the primate and rodent cortex is the voluminous SGL that is either absent or much smaller in rodents. The distribution of $\left[{ }^{3} \mathrm{H}\right] \mathrm{TdR}$-labeled neurons in a series of embryonic monkeys killed at short intervals indicates that most of these cells come from the olfactory placode as suggested on the basis of histological examination of human embryos (Meyer and Wahle, 1999). Furthermore, a small number of radiolabeled cells in the SGL, $1 \mathrm{hr}$ after exposure to $\left[{ }^{3} \mathrm{H}\right] \mathrm{TdR}$, as well as the paucity of mitotic figures and PCNA-immunoreactive cells, indicates that most of the small neurons are not produced locally, within layer I. Thus, as suggested previously, these cells probably originate from outside structures, such as the olfactory primordium and GE, and migrate under the pia, covering the entire cerebral surface (Brun, 1965; Gadisseux et al., 1992; Meyer and Goffinet, 1998; Meyer and Wahle, 1999).

The concept that layer I and subplate neurons are remnants of the early generated preplate cells bisected by the later-generated cells of the cortical plate (Marin-Padilla, 1971; for review, see Aboitiz, 1999) needs modification because of the findings in both human and nonhuman primates. The present $\left[{ }^{3} \mathrm{H}\right] \mathrm{TdR}$ analysis reveals that the majority of layer I neurons are generated long after the split of the preplate (Kostovic and Rakic, 1980). Thus, layer I, like the subplate zone, becomes enlarged and more complex during primate evolution (Kostovic and Rakic, 1990).

\section{Function and fate}

What is the destiny of the transient SGL and the function of embryonic layer I neurons? Some of the SGL cells may partially transform into the small layer I neurons, but the large size of the SGL and the pattern of its dispersion in monkeys indicate that it may also contribute GABAergic neurons to the subjacent cortical plate. Recent studies in rodents indicate that some of the equivalent cells may descend to the cortical plate and differentiate into the GABAergic interneurons (Wichterle et al., 1999; Parnavelas,

Table 2. Total number of neurons \pm SEM per $1000 / \mu \mathrm{m}$ length of layer I at various postnatal ages

\begin{tabular}{|c|c|c|c|c|c|c|}
\hline Age/area & Motor & Sensory & Visual & Prefrontal & Insular & Limbic \\
\hline $2-3 \mathrm{~m}$ & $\begin{array}{c}35.3 \pm 1.4 \\
n=5\end{array}$ & $\begin{array}{c}31.2 \pm 2.1 \\
n=4\end{array}$ & $\begin{array}{c}30.0 \pm 2.8 \\
n=4\end{array}$ & $\begin{array}{c}40.3 \pm 1.5 \\
n=4\end{array}$ & $\begin{array}{c}40.3 \pm 4.3 \\
n=4\end{array}$ & $\begin{array}{c}43.4 \pm 1.1 \\
n=5\end{array}$ \\
\hline $4 \mathrm{~m}(n=1)$ & 31 & 33 & 25 & 25 & NA & 43 \\
\hline Adult $(n=1)$ & 23 & 24.5 & 31.5 & 28.5 & 26 & 23 \\
\hline
\end{tabular}

NA, Not available. 
2000). The areal difference in organization of the SGL between striate and extrastriate cortex (Fig. 4) is in agreement with the reports of cortical regionalization before its innervation (Rakic, 1988; Donoghue and Rakic, 1999b; Sestan et al., 2001; for review, see Rubenstein and Rakic, 1999) and with the previous suggestion of this migration, based on the histology of SGL in the human fetus (Kostovic et al., 1985).

The hypothesis that early generated $\mathrm{C}-\mathrm{R}$ cells coordinate layering and connectivity in the cortical plate during development (Rakic and Caviness, 1995; Marin-Padilla, 1998; Soria and Fairén, 2000; Hevner et al., 2001) is supported by the finding that these cells produce reelin, a glycoprotein missing in reeler mice that show defective settling of cortical neurons and timely maturation of neurons (D'Arcangelo et al., 1995, 1997; Ogawa et al., 1995; Del Rio et al., 1997; Goffinet, 1997; Nakajima et al., 1997). The remarkable perpendicular orientation of the $\mathrm{C}-\mathrm{R}$ cell processes in the plane parallel to the pial surface that is described in the present study may be related to cortical patterning and specification and a more precise geometrical pattern of the laminar and columnar organization in the primate cortex (Rakic, 1995; Mountcastle, 1997). A suggestion that $\mathrm{C}-\mathrm{R}$ cells might coordinate positional information essential for the early areal and columnar specification of the underlying cortex (Schmidt et al., 1996; Schwartz et al., 1998; Gulaske and Singer, 1999; Soria and Fairén, 2000; Hevner et al., 2001) received support from the recent finding that deletion of the Trb- 1 gene, which is expressed in $\mathrm{C}-\mathrm{R}$ cells, perturbs formation of the thalamocortical connections (Hevner et al., 2001).

A common assumption is that only a subset of the C-R cells survives into adulthood (Sidman and Rakic, 1982; Marin-Padilla, 1998; Meyer and Goffinet, 1998) and that many of them change their morphology (Poliakov, 1961; Konig and Marty, 1981; Parnavelas and Edmunds, 1983). The dilution, caused by the growth of the neocortex, may also play a role in the diminishing density of C-R cells in layer I, particularly in humans, in which the thickness of layer I quadruples and the surface expands 200 -fold during postnatal development (Blinkov and Glezer, 1968). However, the "dilution" effect can only partly explain the decrease in $\mathrm{C}-\mathrm{R}$ cell number after puberty when the volume of layer I becomes constant (Bourgeois and Rakic, 1993). Furthermore, the density of all classes of layer I neurons should decline equally if dilution plays a major role in their numerical reduction. This was not the case, because we observed a differential, highly selective elimination of a subpopulation of $\mathrm{C}-\mathrm{R}$ cells. The identification of several subpopulations of layer I cells with selective persistence in primates may help in elucidating their possible role in congenital malformations of the human cerebral cortex such as lissencephaly (Clark et al., 1997; Hong et al., 2000).

\section{REFERENCES}

Abercombie M (1946) Estimation of nuclear population from microtom section. Anat Rec 94:239.

Aboitiz F (1999) Evolution of isocortical organization. A tentative scenario including roles of reelin, $\mathrm{p} 35 / \mathrm{cdk} 5$ and the subplate zone. Cereb Cortex 9:655-661.

Alcantara S, Ruiz M, Ezan F, de Lecea L, Curran T, Sotelo C, Soriano E (1998) Regional and cellular patterns of reelin mRNA expression in the forebrain of the developing and adult mouse. $J$ Neurosci 18:7779-7799.

Anderson SA, Eisenstat DD, Shi L, Rubenstein JL (1997) Interneuron migration from basal forebrain to neocortex: dependence on Dlx genes. Science 278:474-476.

Anderson SA, Mione M, Yun K, Rubenstein JL (1999) Differential origins of neocortical projection and local circuit neurons: role of Dlx genes in neocortical interneuronogenesis. Cereb Cortex 9: 646-654.

Anton ES, Cameron RS, Rakic P (1996) Role of neuron-glial junctional domain proteins in the maintenance and termination of neuronal migration across the embryonic cerebral wall. J Neurosci 16:2283-2293.

Blinkov S, Glezer I (1968) The human brain in figures and tables. A quantitative handbook. New York: Plenum.

Bourgeois J, Rakic P (1993) Changes of synaptic density in the primary visual cortex of the macaque monkey from fetal to adult stage. J Neurosci 13:2801-2820.

Brun A (1965) The subpial granular layer of fetal cerebral cortex in man. Its ontogeny and significance of congenital cortical malformations. Acta Pathol Microbiol Scand Suppl 179:1-98.

Clark G, Mizuguchi M, Antalffy B, Barnes J, Armstrong D (1997) Predominant localization of the LIS family of gene products to CajalRetzius cells and ventricular neuroepitelium in the developing human cortex. J Neuropathol Exp Neurol 56:1044-1052.

Curran T, D'Arcangelo G (1998) Role of reelin in the control of brain development. Brain Res Rev 26:285-294.

D'Arcangelo G, Miao GG, Chen SC, Soares HD, Morgan JI, Curran T (1995) A protein related to extracellular matrix proteins deleted in the mouse mutant reeler. Nature 374:719-723.

D'Arcangelo G, Nakajima K, Miyata T, Ogawa M, Mikoshiba K, Curran $\mathrm{T}$ (1997) Reelin is a secreted glycoprotein recognized by the CR-50 monoclonal antibody. J Neurosci 17:23-31.

De Carlos JA, Lopez-Mascaraque L, Valverde F (1996) Dynamics of cell migration from the lateral ganglionic eminence in the rat. J Neurosci 16:6146-6156.

Del Rio JA, Heimrich B, Borrell V, Forster E, Drakew A, Alcantara S, Nakajima K, Miyata T, Ogawa M, Mikoshiba K, Derer P, Frotscher M, Soriano E (1997) A role for Cajal-Retzius cells and reelin in the development of hippocampal connections. Nature 385:70-74.

Derer P (1985) Comparative localization of Cajal-Retzius cells in the neocortex of normal and reeler mutant mice fetuses. Neurosci Lett 54:1-6.

Donoghue MJ, Rakic P (1999a) Molecular evidence for the early specification of presumptive functional domains in the embryonic primate cerebral cortex. J Neurosci 19:5967-5979.

Donoghue MJ, Rakic P (1999b) Molecular gradients and compartments in the embryonic primate cerebral cortex. Cereb Cortex 9:586-600.

Edmunds SM, Parnavelas JG (1982) Retzius-Cajal cells: an ultrastructural study in the developing visual cortex of the rat. J Neurocytol 11:427-446.

Gadisseux JF, Goffinet AM, Lyon G, Evrard P (1992) The human transient subpial granular layer: an optical, immunohistochemical, and ultrastructural analysis. J Comp Neurol 324:94-114.

Goffinet AM (1997) Developmental neurobiology. Unscrambling a disabled brain. Nature 389:668-669.

Gulaske RA, Singer W (1999) The origin and topography of long-range intrinsic projections in cat visual cortex: a developmental study. Cereb Cortex 6:417-430.

Hevner RF, Shi L, Justice N, Hsueh Y-P, Sheng M, Smiga S, Bulfone A, Goffinet AM, Rubenstein JLR (2001) Tbr1 regulates differentiation of the preplate and layer 6. Neuron 29:353-366.

Hong SE, Haung DT, Shugart YY, Al Shahwan S, Grant PE, Hourihane JOB, Martin NDT, Walsh CA (2000) Autosomal recessive lissencephaly with cerebellar hypoplasia $(\mathrm{LCH})$ is associated with human reelin gene mutations. Nat Genet 26:93-96.

Huntley GW, Jones EG (1990) Cajal-Retzius cells in developing monkey neocortex show immunoreactivity for calcium binding proteins. J Neurocytol 19:200-212.

Impagnatiello F, Guidotti AR, Pesold C, Dwivedi Y, Caruncho H, Pisu MG, Uzunov DP, Smalheiser NR, Davis JM, Pandey GN, Pappas GD, Tueting P, Sharma RP, Costa E (1998) A decrease of reelin expression as a putative vulnerability factor in schizophrenia. Proc Natl Acad Sci USA 95:15718-15723.

Konig N, Marty R (1981) Early neurogenesis and synaptogenesis in cerebral cortex. Bibl Anat 19:152-160.

Konig N, Valat J, Fulcrand J, Marty R (1977) The time of origin of Cajal-Retzius cells in the rat temporal cortex. An autoradiographic study. Neurosci Lett 4:21-26.

Kostovic I, Rakic P (1980) Cytology and time of origin of interstitial neurons in the white matter in infant and adult human and monkey telencephalon. J Neurocytol 9:219-242.

Kostovic I, Rakic P (1990) Developmental history of the transient subplate zone in the visual and somatosensory cortex of the macaque monkey and human brain. J Comp Neurol 297:441-470.

Kostovic I, Kostovic-Knezevic L, Vidic Z (1985) Prenatal and early postnatal development of large, acetylcholinesterase reactive cells in the marginal zone of the human associative cortex: a correlated histochemical and Nissl study. Neurosci Lett Suppl 22:341.

Lavdas A, Grigoriou M, Pachnis V, Parnavelas J (1999) The medial ganglionic eminence gives rise to a population of early neurons in the developing cerebral cortex. J Neurosci 19:7881-7888.

Magini J (1888) Nouvelles recherches, histologique sur le cerveau du foetus. Arch Ital Biol 10:384-387.

Marin-Padilla M (1971) Early prenatal ontogenesis of the cerebral cortex (neocortex) of the cat (Felis domestica). A Golgi study. I. The 
primordial neocortical organization. Z Anat Entwicklungsgesch 134:117-145.

Marin-Padilla M (1998) The Cajal-Retzius cell and the development of the neocortex. Trends Neurosci 21:64-71.

Martinotti C (1890) Beitrag zum studium der Hirnrinde und dem Centralursprung der Nerven.Intern.Monatsschr. Anat Physiol 7:69-90.

Meyer G, Goffinet AM (1998) Prenatal development of reelinimmunoreactive neurons in the human neocortex. J Comp Neurol 397:29-40.

Meyer G, Gonzalez-Hernandez T (1993) Developmental changes in layer I of the human neocortex during prenatal life: a DiI-tracing and AchE and NADPH-d histochemistry study. J Comp Neurol 338:317-336.

Meyer G, Wahle P (1999) The paleocortical ventricle is the origin of reelin-expressing neurons in the marginal zone of the fetal human neocortex. Eur J Neurosci 11:3937-3944.

Meyer G, Soria J, Martinez-Galan J, Martin-Clemente B, Fairen A (1998) Different origins and developmental histories of transient neurons in the marginal zone of the fetal and neonatal rat cortex. J Comp Neurol 397:493-518.

Meyer G, Goffinet A, Fairen A (1999) What is a Cajal-Retzius cell? A reassessment of a classical cell type based on recent observations in the developing cortex. Cereb Cortex 9:765-775.

Meyer G, Schaaps J-P, Moreau L, Goffinet AM (2000) Embryonic and early fetal development of the human neocortex. J Neurosci 20:1858-1868

Mountcastle VB (1997) The columnar organization of the neocortex. Brain 120:701-722.

Nakajima K, Mikoshiba K, Miyata T, Kudo C, Ogawa M (1997) Disruption of hippocampal development in vivo by CR-50 mAb against reelin. Proc Natl Acad Sci USA 94:8196-8201.

Ogawa M, Miyata T, Nakajima K, Yagyu K, Seike M, Ikenaka K, Yamamoto H, Mikoshiba K (1995) The reeler gene-associated antigen on Cajal-Retzius neurons is a crucial molecule for laminar organization of cortical neurons. Neuron 14:899-912.

Parnavelas J (2000) The origin and migration of cortical neurons: new vistas. Trends Neurosci 23:126-131.

Parnavelas JG, Edmunds SM (1983) Further evidence that CajalRetzius cells transform to non-pyramidal neurons in the developing rat visual cortex. J Neurocytol 12:863-871.

Pesold C, Impagnatiello F, Pisu MG, Uzunov DP, Costa E, Guidotti A, Caruncho HJ (1998) Reelin is preferentially expressed in neurons synthesizing gamma-aminobutyric acid in cortex and hippocampus of adult rats. Proc Natl Acad Sci USA 95:3221-3226.

Poliakov GI (1961) Some results of research into the development of the neuronal structure of the cortical ends of the analyzers in man. J Comp Neurol 117:197-212.

Rakic P (1971) Neuron-glia relationship during granule cell migration in developing cerebellar cortex. A Golgi and electron microscopic study in Macacus rhesus. J Comp Neurol 141:283-312.

Rakic P (1972) Mode of cell migration to the superficial layers of fetal monkey neocortex. J Comp Neurol 145:61-83.

Rakic P (1973) Kinetics of proliferation and latency between final cell division and onset of differentiation of cerebellar stellate and basket neurons. J Comp Neurol 147:523-546.

Rakic P (1985) Limits of neurogenesis in primates. Science 227:154-156.

Rakic P (1988) Specification of cerebral cortical areas. Science 241: $170-176$.
Rakic P (1995) Radial versus tangential migration of neuronal clones in the developing cerebral cortex. Proc Natl Acad Sci USA 92: 11323-11327.

Rakic P, Caviness Jr VS (1995) Cortical development: view from neurological mutants two decades later. Neuron 14:1101-1104.

Ramon y Cajal S (1891) Sur la structure de l'ecorce cerebrale de quelques mammiferes. La Cellule 7:125-176.

Ramon y Cajal S (1911) Histologie du System Nerveux de l'Homme et des Vertebres, Vol 2. Paris: Malonine.

Retzius G (1893) Die Cajal'shen Zellen der Grosshirnrinde beim Menschen und bei Saugethieren. Biol Unters Neue Folge 5:1-8.

Rubenstein JR, Rakic P (1999) Genetic control of cortical development. Cereb Cortex 9:521-523.

Schaffer K (1918) Uber normale und pathologischen Hirnfurchung. Z Ges Neurol Psychiat 38:1-77.

Schiffmann SN, Bernier B, Goffinet AM (1997) Reelin mRNA expression during mouse brain development. Eur J Neurosci 9:1055-1071.

Schmidt KE, Gulaske RAW, Singer W (1996) Matching the modules: cortical maps and long range intrinsic connections in visual cortex during development. J Neurobiol 41:10-17.

Schwartz TH, Rabinowitz D, Unni V, Kumar VS, Smetters DK, Tsiola A, Yuste R (1998) Networks of coactive neurons in developing layer 1. Neuron 20:541-552.

Sestan N, Rakic P, Donoghue MJ (2001) Independent parcellation of the embryonic visual cortex and thalamus revealed by combinatorial Eph/ ephrine gene expression. Curr Biol 11:39-43.

Shoukimas GM, Hinds JW (1978) The development of the cerebral cortex in the embryonic mouse: an electron microscopic serial section analysis. J Comp Neurol 179:795-830.

Sidman RL, Rakic P (1973) Neuronal migration with special reference to developing human brain: a review. Brain Res 62:1-35.

Sidman RL, Rakic P (1982) Development of the human central nervous system. In: Histology and histopathology of the nervous system (Haymaker W, Adams RD, eds), pp 3-145. Springfield, IL: Thomas.

Soria JM, Fairén A (2000) Cellular mosaics in the rat marginal zone define an early neocortical territorialization. Cereb Cortex 10:400-412.

Spreafico R, Arcelli P, Frassoni C, Canetti P, Giaccone G, Rizzuti T, Mastrangelo M, Bentivoglio M (1999) Development of layer I of the human cerebral cortex after midgestation. J Comp Neurol 410:126-142.

Valverde F, De Carlos JA, Lopez-Mascaraque L (1995) Time of origin and early fate of preplate cells in the cerebral cortex of the rat. Cereb Cortex 5:483-493.

Verney C, Derer P (1995) Cajal-Retzius neurons in human cerebral cortex at midgestation show immunoreactivity for neurofilament and calcium-binding proteins. J Comp Neurol 359:144-153.

Wichterle H, Garcia-Verdugo JM, Herrera DG, Alvarez-Buylla A (1999) Young neurons from medial ganglionic eminence disperse in adult and embryonic brain. Nat Neurosci 2:461-466.

Wilson SW, Rubenstein JL (2000) Induction and dorsoventral patterning of the telencephalon. Neuron 28:641-651.

Zecevic N, Milosevic A (1997) Initial development of gammaaminobutyric acid immunoreactivity in the human cerebral cortex. J Comp Neurol 380:495-506.

Zecevic N, Rakic P (1991) Synaptogenesis in monkey somatosensory cortex. Cereb Cortex 1:510-523.

Zecevic N, Milosevic A, Rakic S, Marin-Padilla M (1999) Early development and composition of the human primordial plexiform layer: an immunohistochemical study. J Comp Neurol 412:241-254. 